\title{
Insufficient risk assessment of herbicide-tolerant genetically engineered soybeans intended for import into the EU
}

\author{
Juliana Miyazaki ${ }^{1}$, Andreas Bauer-Panskus', Thomas Bøhn², Wolfram Reichenbecher ${ }^{3}$ and Christoph Then ${ }^{\text {* }}$
}

\begin{abstract}
The introduction of herbicide-tolerant (HT) genetically engineered (GE) soybeans has raised new challenges for the European risk assessment of imported food and feed. Food and feed products derived from these plants may show specific patterns of chemical residues and altered nutritional composition. Furthermore, there has been a substantial increase in the usage of herbicides in soybean production due to the emergence of resistant weeds. This concerns particular glyphosate-based herbicides and also other herbicides. In this review, we give an overview of available data regarding glyphosate application on HT GE soybeans in North and South America. We have further compared this data with herbicide applications in experimental field trials conducted by the industry. We conclude that field trials carried out for risk assessment purposes do not generally represent the real agronomic conditions in commercial HT GE plant cultivation. In most cases, neither the applied dose nor the number of applications match real conditions. This finding is especially relevant for risk assessment since a review of relevant publications shows that the amount and timing of spraying glyphosate as a complementary herbicide onto HT GE plants can impact their composition; this is relevant to EFSA comparative risk assessment of GMOs. Further, closely related issues were identified that overlap with EU GMO and pesticide regulation, but are not currently considered. These issues concern indirect, cumulative and combinatorial effects as well as the assessment of mixed toxicity. Consequently, current risk assessment practice for HT GE plants cannot be considered to fulfil EU regulatory standards which require the safety of food and feed to be demonstrated. It is much more likely that concerns about the health risks of HT GE plant material used for food and feed have been underestimated. We therefore conclude that the EU risk assessment of food and feed derived from HT GE plants needs substantial improvement.
\end{abstract}

Keywords: Genetically engineered plants, Herbicide tolerance, Glyphosate, Complementary herbicides, Risk assessment, Health risk assessment, European Food Safety Authority EFSA, Herbicide residue, GMO regulation, Pesticide regulation

\section{Background}

HT GE soybeans were introduced in the 1990s to agricultural systems in the USA and several countries in South America, such as Argentina, Brazil, Paraguay and Uruguay. Herbicide tolerance, in particular to glyphosate, is still a dominant trait in GE plants, including glyphosatetolerant "Roundup Ready" soybeans. According to the

\footnotetext{
${ }^{*}$ Correspondence: christoph.then@testbiotech.org

${ }^{1}$ Testbiotech e.V, Institute for Independent Impact Assessment of Biotechnology, Frohschammerstr. 14, 80807 Munich, Germany Full list of author information is available at the end of the article
}

EU Commission [1], the percentage of GE glyphosatetolerant soybeans cultivated in 2014 in Brazil, the USA and Paraguay made up around $90 \%$ of production, and in Argentina and Uruguay even reached 100\%. The EU imports around 33 million tons of soybeans and soymeal per year [2]. By mid-2019, the EU had authorised $20 \mathrm{GE}$ soybean events for import, most of them resistant to glyphosate and some of them resistant to other active ingredients as well (see Table 1).

Herbicide resistance in GE technology was adopted rapidly in soybean growing regions, because it simplified weed control and promised cost reductions $[4,5]$. 
Table 1 List of glyphosate-tolerant soybeans approved in the EU for food and feed (Testbiotech, 2019 [3])

\begin{tabular}{|c|c|c|c|}
\hline Event & GE plants resistant to... & Other traits & Applicant \\
\hline DP356043 & Glyphosate, ALS inhibitors & & Pioneer/DuPont \\
\hline $40-3-2$ & Glyphosate & & Monsanto \\
\hline MON87701 × MON89788 & Glyphosate & Producing insecticidal proteins & Monsanto \\
\hline MON87705 & Glyphosate & Changed oil composition & Monsanto \\
\hline MON89788 & Glyphosate & & Monsanto \\
\hline FG72 & Glyphosate, isoxaflutole & & Bayer CropScience \\
\hline MON87708 × MON89788 & Glyphosate, dicamba & & Monsanto \\
\hline MON87705 × MON89788 & Glyphosate & Changed oil composition & Monsanto \\
\hline DP305423 × 40-3-2 & Glyphosate, ALS inhibitors & Changed oil composition & Pioneer/DuPont \\
\hline $\mathrm{FG72} \times \mathrm{A} 5547-127$ & Glyphosate, glufosinate, isoxaflutole & & Bayer CropScience \\
\hline DAS-44406-6 & Glyphosate, 2,4-D, glufosinate & & Dow AgroSciences \\
\hline
\end{tabular}

Ploughing to control weeds was replaced by applying the broad-spectrum herbicide glyphosate, thereby supporting the widespread application of no-till farming for the cultivation of GE soybean and other such crops.

This change in agricultural practice led to massive pressure on weeds to evolve resistance to glyphosate. Herbicide resistance in weeds was an issue in many regions before HT GE soybeans were introduced, but no glyphosate-resistant weed species were known in the soybean growing areas. At that time, about $25 \%$ of the soybean acreage in the USA was sprayed with four or more herbicide-active ingredients, while only around 10\% was treated with just one single active ingredient per year [6]. After the introduction of HT GE soybeans, the use of glyphosate increased strongly, while the use of other active ingredients was reduced as was the number of sprayings [6]. Interestingly, during this development, the overall amount of herbicides applied in soybean fields in the USA was not reduced. There was instead a slight increase from an average treatment rate of $1.04 \mathrm{lbs}$ in 1995 to 1.08 lbs per acre in 1998 [6]. The amount of active ingredients (a.i.) increased from 0.61 to $0.92 \mathrm{lbs}$ per acre [6], which equals $0.68 \mathrm{~kg}$ (a.i.) to $1.03 \mathrm{~kg}$ (ai.)/ha.

Scientists working for Monsanto in 1997 [7] and 2000 [8] claimed that the development of weed resistance to glyphosate should be expected to be a very rare event. As Croon et al. [8] explain:

"Although it cannot be stated that evolution of resistance to glyphosate will not occur, the development of weed resistance to glyphosate is expected to be a very rare event because:

1. Weeds and crops are inherently not tolerant to glyphosate, and the long history of extensive use of glyphosate has resulted in few instances of resistant weeds.
2. Glyphosate has many unique properties, such as its mode of action, chemical structure, limited metabolism in plants, and lack of residual activity in soil, which make the development of resistance unlikely.

3. Selection for glyphosate resistance using whole plant and cell/tissue culture techniques was unsuccessful, and would, therefore, be expected to occur rarely in nature under normal field conditions." (page 52/53).

It is noteworthy that at that time, the first cases of glyphosate resistance were already being reported; starting in 1996 with a case of herbicide-resistant rigid ryegrass in Australia [9]. Nevertheless, regulators did not take regulatory action regarding weed resistance management. As a result, in November 2019, according to an international register [9], there were already 47 different glyphosate-resistant weed species known to occur. Well-known examples are rigid ryegrass (Lolium rigidum), Johnsongrass (Sorghum halepense), Palmer amaranth (Amaranthus palmeri), Italian ryegrass (Lolium perenne ssp. multiflorum) or horseweed (Conyza canadensis). There are 17 species known to occur in the USA, 9 in Brazil and 15 in Argentina. Since these weeds are known to affect a large proportion of the acreage where soybeans are grown [10], there are good reasons to expect that in these areas more glyphosate was sprayed to control the weeds, using higher dosages, alone or in combination with other herbicides. This review focuses on the health risks of HT GE soybeans at the stage of consumption. We give an overview of available data on the amount of herbicides, in particular glyphosate, used in HT GE soybean cultivation in North and South America. We include a discussion of how recent pattern of herbicide usage affects EU 
GMO risk assessment for food and feed safety when applications are filed for market approval and import.

\section{The interface between pesticide and GMO regulation in the EU}

Current European Food Safety Authority (EFSA) risk assessment of HT GE plants is divided into two parts: assessment of the GE organism by the GMO Panel, and assessment of the pesticide by the Pesticide Panel. Both assessments have different legal frameworks, which arein regard to the risk assessment of food safety-both linked to the Regulation (EC) No 178/2002.

\section{GMO regulation in the EU}

Regulation (EC) No 1829/2003 in combination with Directive 2001/18/EC and Implementing Regulation (EU) No 503/2013 is the most relevant for the risk assessment of GE plants: the provisions in Regulation (EC) No 1829/2003 aim to protect human and animal health, food and feed that consist of, contain, or are produced from GE organisms (which are called genetically modified organisms, GMO), which should undergo a risk and safety assessment before being placed on the market in the European Union. Its recitals 2, 3 and 9 clarify that: (a) "A high level of protection of human life and health should be ensured in the pursuit of [Union] policies"; (b) "In order to protect human and animal health, food and feed consisting of, containing or produced from genetically modified organisms...should undergo a safety assessment through a [Union] procedure before being placed on the market within the [Union]"; and (c) "(...) genetically modified food and feed should only be authorised for placing on the Community market after a scientific evaluation of the highest possible standard, to be undertaken under the responsibility of [EFSA], of any risks which they present for human and animal health and, as the case may be, for the environment (...)".

Food and feed that consists of, contains or is produced from GE organisms must not "have adverse effects on human health, animal health or the environment" (Articles 4(1)(a) and 16(1)(a) of Regulation (EC) No 1829/2003) or "differ from the food which it is intended to replace to such an extent that its normal consumption would be nutritionally disadvantageous for the consumer" and/or "differ from feed which it is intended to replace to such an extent that its normal consumption would be nutritionally disadvantageous for animals or humans" (Articles 4(1)(c) and 16(1)(d) of the Regulation (EC) No $1829 / 2003)$.

In addition, Implementing Regulation (EU) No 503/2013 requests that "the comparative analysis of composition and agronomic as well as phenotypic characteristics shall constitute, together with the molecular characterisation, the starting point to structure and conduct the risk assessment of a new genetically modified food and feed."

There are some difficulties inherent in this approach to the risk assessment of GE organisms:

Current EFSA risk assessment of HT GE is divided into the assessment of the organism performed by the GMO Panel, and assessment of the pesticide performed by the Panel on Plant Protection Products and their Residues (PPR). This separation raises the question about gaps in the risk assessment of food safety of the GMOs sprayed with the pesticide. The risk assessment needs to ensure that the safety of the organism as a whole (as well as food and feed derived thereof) is shown and is not reduced to the assessment of some single parts or pieces.

Moreover, risk assessment of GE organisms cannot always be narrowed down to well-defined potential hazards or be reduced to very specific potential adverse effects but includes uncertainties. The EU risk assessment tries to overcome this problem with a so-called 'comparative approach' where GE plants are grown side by side with their conventional counterparts in experimental field trials and then both are compared regarding some phenotypic characteristics (such as height, yield and flowering) and selected compounds.

Implementing Regulation (EU) No 503/2013 is providing detailed requirements about which practices must be taken into account and which standards have to be applied in providing and assessing the relevant data. The following provisions of its Annex II are of specific relevance for the risk assessment of HT GE plants: "In the case of herbicide tolerant genetically modified plants and in order to assess whether the expected agricultural practices influence the expression of the studied endpoints, three test materials shall be compared: the genetically modified plant exposed to the intended herbicide; the conventional counterpart treated with conventional herbicide management regimes; and the genetically modified plant treated with the same conventional herbicide management regimes." (Annex II, 1.3.1) "The different sites selected for the field trials shall reflect the different meteorological and agronomic conditions under which the crop is to be grown; the choice shall be explicitly justified. The choice of non-genetically modified reference varieties shall be appropriate for the chosen sites and shall be justified explicitly." (Annex II, 1.3.1.2.1 (b)).

\section{Pesticide regulation in the EU}

Regulation (EC) No 1107/2009 is the one most pertinent for placing plant protection products on the market, and Regulation (EC) No 396/2005 for setting maximum residue levels (MRLs) of pesticides in food and feed. Both regulations require a high level of protection for health 
and the environment (see, for example, Recitals 8 and 24 and Article 1.4 of Regulation (EC) No 1107/2009 as well as Recital 5 and Article 1 of Regulation (EC) No $396 / 2005)$. Consequently, safety needs to be established and substances or products produced or placed on the EU market should not have any harmful effects on human or animal health.

More specifically, Article 29 of Regulation (EC) No $1107 / 2009$ requests that active substances as well as synergists have to be approved, and the maximum residue levels of pesticides for specific agricultural products have to be determined. Article 4 states that pesticides must not have any harmful effects on human or animal health, taking into account known cumulative and synergistic effects. Further provisions can be found in Regulation (EC) No 396/2005: (i) Recital 5 states that residues should not be present at levels presenting an unacceptable risk to humans and, where relevant, to animals; (ii) Recital 10 requests that specific MRLs for each pesticide in food and feed products have to be established; (iii) Recital 26 is highly relevant for imported products derived from HT GE plants, since it requests that MRLs have to be set for food and feed produced outside the community if produced by different agricultural practices (use of plant protection products); (iv) Article 14 adds that the presence of pesticide residues originating from sources other than current plant protection uses and their known cumulative and synergistic effects have to be determined, as well as "the results of any evaluations and decisions to modify the uses of plant protection products" (Article 14.2 (d)).

Consequently, further investigation of the residues from spraying with the complementary herbicide may be required even if a particular pesticide is authorised for use on plants grown in the EU, or imported from a third country. In the case of the cultivation of HT GE plants, several aspects linked to herbicides require special attention, e.g. the patterns of application and exposure, the occurrence of specific metabolites and combinatorial effects. As Kleter et al. [11] point out, HT GE crops can change the way herbicides can be used on these crops, e.g. (a) post-emergent over-the-top applications (i.e. on the crop itself) instead of directed sprays, avoiding herbicide contact with the crop; or (b) pre-emergent and preharvest applications made to the conventional crop and not, or in different quantities, to the GM crop. Further, and depending on the specific trait, residue profiles may be very specific, i.e. when the herbicide is metabolised by the introduced protein. As a result, consumption of food and feed products derived from HT GE plants can be associated with an exposure to herbicide residues that is different in quantity and quality compared to products derived from other crop plants.
The interface between pesticide and GMO regulation Under EU regulation, applications for authorisation of GE organisms in the EU must contain a comprehensive safety and environmental risk assessment which must address any potentially adverse effect on human health and the environment. This requirement includes longterm potential and cumulative effects and also other harmful effects on human or animal health. Residues from the use of complementary herbicides are crucial in this context. Consequently, authorisation for import and use of food and feed cannot be granted if GE plants containing residues from complementary herbicides pose unacceptable risks, or are suspected of causing harm to human as well as animal health.

As shown above, there are several provisions for the assessment of health risks in both EU GMO and pesticide regulation: (i) both require a high level of protection for health and the environment, and (ii) both request that the conditions of agricultural production are considered. (iii) Moreover, both request that combinatorial effects are taken into account. (iv) Finally, Implementing Regulation (EU) No 503/2013 explicitly addresses these two areas of risk assessment by requesting field trials with and without the application of the complementary herbicide. However, this conceptual split addressing issues related to the use of complementary herbicides in two regulations disregards that HT GE plants plus complementary herbicide(s) are a system designed to be routinely used in combination.

\section{Comparing data on the amount of complementary herbicides applied for cultivation and applied for risk assessment studies}

Using increased amounts of complementary herbicides for HT GE soybeans raises two crucial questions:

(1) What are the current practices in the cultivation of HT GE soybeans in terms of use of complementary herbicides?

(2) Are these practices reflected in the studies submitted in requests for authorisation of GE soybeans for import, food and feed use in the EU?

\section{Current practice in the cultivation of HT GE soybeans in terms of use of complementary herbicides}

Starting from spraying $1.03 \mathrm{~kg}$ active ingredient (a.i.)/ ha (0.92 lbs (a.i.)/acre) in 1998 [6], there has been a substantial increase in the usage of glyphosate in soybean production per hectare. This is evident from numbers of different sources. For example, Bindraban et al. [12] report $3.84 \mathrm{~kg}$ (a.i.)/ha in 2007, Benbrook [10] reports 
around $4 \mathrm{~kg}$ (a.i.)/ha to be sprayed in Argentina and Brazil in 2014, while Monsanto, in its product label, recommends about $7 \mathrm{~kg}$ (a.i.)/ha to be sprayed [13]. Official figures from the USDA database [14] show that up to 6-7 kg (a.i.)/ha of glyphosate can be expected in soybean cultivation, including pre- and post-emergence applications. Further, Monsanto, in a patent application which deals with "cropping systems for managing weeds" [15], recommends spraying up to $8 \mathrm{~kg}$ (a.i.)/ha in HT soybeans. This amount corresponds to product label recommendations for the maximum overall application per year [13]. After having investigated representative figures for farmer use, we assume that even $10 \mathrm{~kg}$ (a.i.)/ha of glyphosate per year is not unrealistic nowadays for some regions, such as Argentina, where HT GE soybeans are grown (see, for example, [16]).

Table 2 gives an overview of some data on glyphosate spraying in regions of North and South America where soybeans are grown. Although this overview is far from complete, it allows some overall conclusions to be drawn since it includes data on the amount of active ingredient, the number (frequency) and the timing of the spraying (pre- or post-emergence). The data in Table 2 need some interpretation since they refer to different situations.
Regional weed pressure and applications of other active ingredients that might partially replace glyphosate vary, especially in case of 'stacked' plants resistant to several active ingredients (glufosinate, 2,4-D, dicamba or isoxaflutole). Also, there are several strategies to control weeds such as applying high amounts of different herbicides before cultivation (pre-emergence) and in parallel reducing the amounts of herbicides during cultivation (post-emergence).

From the data available it is clear that repeated sprayings during cultivation (on-plant or post-emergence) have increased significantly, and also that the overall dosage, i.e. the total amount, applied to glyphosate-resistant GE soybeans is much higher compared to figures from 1998, e.g. $1.03 \mathrm{~kg}$ (a.i.)/ha [6]. It can be assumed for postemergence applications that 3-4 kg (a.i.)/ha of glyphosate from two to three sprayings is a reasonable rate, at least in South America. For the overall dosage (pre- and postemergence), 6-7 kg (a.i.)/ha seems to be relatively common and even $8-10 \mathrm{~kg}$ (a.i.)/ha can be expected under current farming conditions in some regions (such as Argentina and Paraguay; see also [25]).

The amount and frequency of herbicide spraying can vary substantially on a local or regional scale. For

Table 2 Some data on the amount of glyphosate application in regions where GE soybeans are grown. Unless otherwise indicated, the amount of glyphosate is given in $\mathrm{kg}$ (a.i.)/ha

\begin{tabular}{|c|c|c|c|c|c|}
\hline Author & $\begin{array}{l}\text { Total amount } \\
\text { of glyphosate }\end{array}$ & Country & Frequency & Timing & Data source \\
\hline Avila-Vazquez et al. [16] & 10 & Argentina & Approx. 12 & $60 \%$ pre-emergence & Survey \\
\hline Benbrook [10] & 4.45 & Argentina & 3.17 & n.i. & Database analysis \\
\hline Bindraban et al. [12] & 3.84 & Argentina & n.i. & n.i. & Literature research \\
\hline Primost et al. [17] & 1.9 to 9.1 average: 3.9 & Argentina & 2-6 (average 3.3) & n.i. & Survey \\
\hline Papa and Tuesca [18] & Approx. 5 & Argentina & n.i. & n.i. & $\begin{array}{l}\text { Calculation based on publicly } \\
\text { accessible data }\end{array}$ \\
\hline Benbrook [10] & 4.45 & Brazil & 3.17 & n.i. & Database analysis \\
\hline Bombardi [19] & 8.4 & Brazil & n.i. & n.i. & $\begin{array}{l}\text { Calculation based on publicly } \\
\text { accessible data }\end{array}$ \\
\hline Pignati et al. [20] & 4.9-6.1 I/ha & Brazil & n.i. & $\begin{array}{l}\text { 1-2 I/ha pre-emergence } \\
\text { and } \\
3-4 \text { I/ha post-emergence }\end{array}$ & Database analysis \\
\hline Pignati et al. [21] & 5.5 l/ha & Brazil & n.i. & n.i. & Database analysis \\
\hline OMAFRA [22] & $1.8-2.7$ & Canada & $1-2$ & $\begin{array}{l}0.9 \text { pre-emergence } \\
0.9-1.8 \text { post-emergence }\end{array}$ & Guide to weed control \\
\hline Franceschell [23] & 4.15 & Paraguay & n.i. & n.i. & $\begin{array}{l}\text { Calculation based on publicly } \\
\text { accessible data }\end{array}$ \\
\hline Benbrook [10] & $1.6-2.08$ & USA & 1.7 & n.i. & Database analysis \\
\hline $\begin{array}{l}\text { Monsanto patent applica- } \\
\text { tion [15] }\end{array}$ & 8 & USA & $3-5$ & Pre- and post-emergence & Patent application \\
\hline Monsanto [13] & Max. approx. 8 & USA & n.i. & Pre- and post-emergence & Roundup product label \\
\hline Perry et al. [24] & 1.5 & USA & n.i. & n.i. & Database analysis \\
\hline USDA [14] & 7 & USA & $1.1-1.5$ & n.i. & Database entry \\
\hline
\end{tabular}

n.i. not indicated in the studies 
example, lower dosages of glyphosate may be the result of replacing glyphosate with other complementary herbicides such as dicamba and 2,4-D (Fig. 1). However, this does not alter the overall trend of sharply increased use of herbicides on HT GE soybeans in North and South America. Almeida et al. [26] analysed pesticide use in Brazil between 2000 and 2012 and reported an increase of more than $120 \%$ per hectare for soybeans. A similar trend can also be observed in the USDA data [14] which is illustrated in Fig. 1.

\section{Amount of glyphosate applied in field trials for EU approval process}

To investigate to what extent agricultural practices were taken into account within the EU approval process and for health risk assessment, we requested field trial studies from EFSA filed by applicants for the approval of HT soybeans in the EU. These studies provide data about the amount of glyphosate that was sprayed in pre- and post-emergence. Table 3 gives an overview of studies filed by Monsanto and Bayer and the amount of glyphosate sprayed. Referring to post-emergence applications, the data show that both companies applied dosages of glyphosate (mostly about 1-2 kg (a.i.)/ha) in experimental field trials which is much lower compared to dosages used by farmers or what is recommended as maximum dosage by both companies (see Table 2).

To investigate the herbicide applications during the field trials in more detail, we compared Bayer's data for its soybeans 'Balance Bean' FG72 and FG72 × A5547127 with data from DowDuPont's soybean 'Enlist' DAS44406-6. The last two confer triple HT: the stacked event FG72 $\times$ A5547-127 is resistant to glyphosate, glufosinate and isoxaflutole (see [27]); the single event 'Enlist' is resistant to glyphosate, glufosinate and 2,4-D (see [28]).

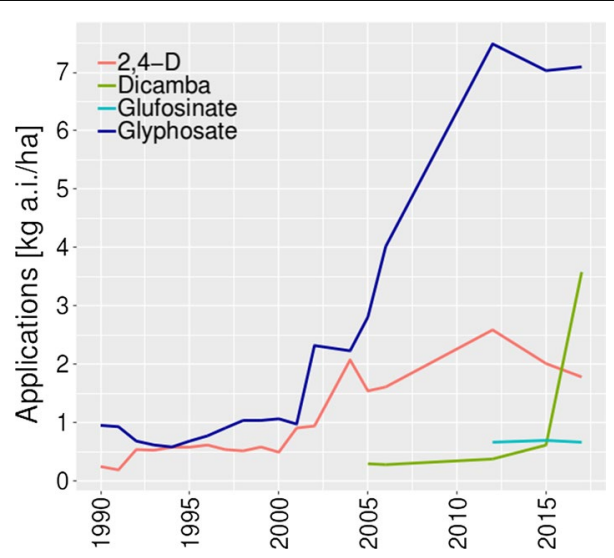

Fig. 1 Herbicide applications (kg (a.i.)/ha) on soybean fields in the USA between 1990 and 2017 (pre- and post-emergence). (Source: USDA [14])
The data show huge differences between the companies in the overall amount sprayed and the number of sprayings (Table 4): Bayer generally applied much lower dosages (amount per ha) of glyphosate and glufosinate compared to DowDuPont. Further, also within the data from one company (DowDuPont), the dosages and the number of herbicides (three for the compositional study and two for the feeding study) varied between the two listed studies. However, EFSA [27, 28] does not take these differences into account.

For the interpretation of the data and comparison with the ones in Table 2, it should be noted that under practical conditions, each of the GE soybeans in Table 4 can be sprayed with glyphosate alone or in combination with one or two of the other active ingredients. Each farmer makes individual decisions and is likely to be influenced by the prevalent weed species, costs and regional agronomic practices. When herbicides are sprayed in combination, their dosage (as active ingredient) might be lower than spraying them singly (cf. Figure 1). However, this issue was not taken into account in the field trials. For example, plants sprayed with glyphosate only were not compared to plants sprayed with several active ingredients. This is in contrast to what has to be expected in practice: for example, until 2018, isoxaflutole was not authorised for application on soybeans in the USA. Therefore, it is likely that before 2018 US farmers applied higher amounts of glyphosate than what can be expected when combined with isoxaflutole.

Further, plants and resulting varieties, such as those marketed as 'Balance Bean' or 'Enlist' with resistance to 2,4-D and isoxaflutole, were not made resistant to a single active ingredient, but to a whole group of them: isoxaflutole belongs to the group of HPPD inhibitors and 2,4-D to the group of phenoxy herbicides. According to a patent for mutated HPPD enzymes conferring resistance against HPPD inhibitors [29], most commercially available HPPD inhibitor herbicides belong to one of four chemical families. According to available publications, FG72 soybean is resistant to HPPD inhibitors belonging to two different families, i.e. isoxaflutole and mesotrione [30]. However, members of the mesotrione family were not considered in field trials.

In addition, as patent application WO2007053482 filed by Dow AgroSciences [31] shows, GE plants, such as DAS-44406-6, which produces the enzyme AAD12, are not only resistant to 2,4-D, but also to further herbicides classified as pyridyloxyacetates. Substances such as triclopyr, fluroxypyr and MCPA are members of this group. Thus, under practical conditions, the farmers have a choice to add other active herbicide ingredients to their weed management. These additional active ingredients 
Table 3 Data on the application of glyphosate in field trials with various HT GE soybeans. Field trials were submitted by Monsanto and Bayer for requesting authorisation of various HT GE soybeans in the EU for import and food and feed use

\begin{tabular}{|c|c|c|c|c|c|c|}
\hline Event & Applicant & $\begin{array}{l}\text { GE plants made } \\
\text { resistant to... }\end{array}$ & $\begin{array}{l}\text { Field trials } \\
\text { conducted } \\
\text { in ... }\end{array}$ & $\begin{array}{l}\text { Amount } \\
\text { of glyphosate } \\
\text { applied }\end{array}$ & Stage & $\begin{array}{l}\text { Total amount } \\
\text { of glyphosate } \\
\text { applied }\end{array}$ \\
\hline $\mathrm{FG72} \times \mathrm{A} 5547-127$ & Bayer CropScience & $\begin{array}{l}\text { Glyphosate, glufosi- } \\
\text { nate, isoxaflutole }\end{array}$ & USA & $<1$ & Before flowering (V5) & $<1$ \\
\hline $\mathrm{FG} 72$ & Bayer CropScience & $\begin{array}{l}\text { Glyphosate, isoxaflu- } \\
\text { tole }\end{array}$ & USA & $<1$ & Before flowering (V5) & $<1$ \\
\hline MON87701 × MON89788 & Monsanto & Glyphosate & Argentina & $\sim 1.5$ & V6 to V8 & $\sim 1.5$ \\
\hline MON87705 & Monsanto & Glyphosate & USA & $<1$ & Pre-emergence & $<1$ \\
\hline MON87705 × MON89788 & Monsanto & Glyphosate & USA & $\sim 1-1.5$ & V2-R1 & $\sim 1-1.5$ \\
\hline MON87708 × MON89788 & Monsanto & Glyphosate, dicamba & USA & $<1$ & $\begin{array}{l}\text { Around flowering } \\
\text { (V4-R1) }\end{array}$ & $<1$ \\
\hline \multirow[t]{9}{*}{ MON89788 } & Monsanto & Glyphosate & USA, Argentina & „label use rate“ & & $?$ \\
\hline & & & USA & $\sim 2$ & Pre-emergence & $\sim 4$ \\
\hline & & & & $\sim 2$ & $\mathrm{~V} 3$ and $\mathrm{R} 1 / \mathrm{R} 2$ & \\
\hline & & & USA & $\sim 3$ & V3 and R1/R2 & $\sim 3$ \\
\hline & & & USA & $\sim 4$ & V2 and $\sim$ V3/4 & $\sim 4$ \\
\hline & & & USA & $\sim 3$ & Pre-emergence & $\sim 6$ \\
\hline & & & & $\sim 2$ & V3 and R1/R2 & \\
\hline & & & & $\sim 1$ & Pre-harvest & \\
\hline & & & USA & $\sim 1$ & $?$ & $\sim 1$ \\
\hline \multirow[t]{6}{*}{ RR 40-3-2 } & Monsanto & Glyphosate & USA & $\sim 6$ & Pre-emergence & $\sim 7$ \\
\hline & & & & $<1$ & Before flowering (V5) & \\
\hline & & & USA & $\sim 6$ & Pre-emergence & $\sim 8$ \\
\hline & & & & $<1$ & Early post-emergence & \\
\hline & & & & $<1$ & Flowering & \\
\hline & & & France, Italy & $<1$ & $\begin{array}{l}\text { Early post-emergence } \\
\text { (V5) }\end{array}$ & $\sim 2$ \\
\hline
\end{tabular}

The data were accessed via EFSA. The amount of glyphosate is given in $\mathrm{kg}$ (a.i.)/ha. When glyphosate was applied more than once, the total amount of glyphosate differs from the application rate

Table 4 Amount of herbicides applied in $\mathbf{k g}$ (a.i.) and number of sprayings in field trials with multiple resistant GE soybeans as conducted by Bayer and DowDuPont for risk assessment of FG72, FG72 x A5547-127 and DAS-44406-6 for import and use as food and feed in the EU

\begin{tabular}{|c|c|c|c|c|}
\hline GE soybean event & Field trial with FG72 & Field trial with FG72 x A5547-127 & Field trial with DAS-44406-6 & Field trial with DAS-44406-6 \\
\hline $\begin{array}{l}\text { Purpose } \\
\text { of the study }\end{array}$ & $\begin{array}{l}\text { Compositional } \\
\text { analysis }\end{array}$ & Compositional analysis & Compositional analysis & Feeding study \\
\hline Glyphosate & $\begin{array}{l}\text { Approx. } 1 \mathrm{~kg} / \mathrm{ha} \\
1 \times \text { spraying }\end{array}$ & $\begin{array}{l}0.863 \mathrm{~kg} / \mathrm{ha} \\
1 \times \text { spraying }\end{array}$ & $\begin{array}{l}3.780 \mathrm{~kg} / \mathrm{ha} \text { (total) } \\
3 \times \text { sprayings }\end{array}$ & $\begin{array}{l}1.68 \text { kg/ha (total) } \\
2 \times \text { sprayings }\end{array}$ \\
\hline Glufosinate & & $\begin{array}{l}0.448 \mathrm{~kg} / \mathrm{ha} \\
1 \times \text { spraying }\end{array}$ & $\begin{array}{l}0.8 \mathrm{~kg} / \mathrm{ha} \text { (total) } \\
2 \times \text { sprayings }\end{array}$ & None \\
\hline Isoxaflutole & $\begin{array}{l}70 \text { mg/ha } \\
1 \times \text { spraying }\end{array}$ & $\begin{array}{l}70 \mathrm{mg} / \mathrm{ha} \\
1 \times \text { spraying }\end{array}$ & & \\
\hline 2,4-D & & & $\begin{array}{l}3.360 \mathrm{~kg} / \mathrm{ha} \text { (total) } \\
3 \times \text { sprayings }\end{array}$ & $\begin{array}{l}1 \mathrm{~kg} / \mathrm{ha} \\
1 \times \text { spraying }\end{array}$ \\
\hline
\end{tabular}

were not considered in field trials and thus not by EFSA in their risk assessment.
In conclusion, Bayer's and Monsanto's herbicide applications are not representative of the agronomic conditions under which these plants are grown. DowDuPont's 
field trials with repeated spraying and higher total amount of herbicides applied are closer to the practical conditions than Bayer's field trials. However, the question remains why DAS-44406-6 soybean materials for the 90-day feeding study and for compositional analysis were produced under different conditions. Soybeans for the feeding study were sprayed with much less glyphosate and 2,4-D and no glufosinate at all. Therefore, the feeding study, which could have shown adverse effects of herbicide residues or other parameters, tested non-representative soybean material. All three companies performed field trials with only one herbicide regime, i.e. a combination of complementary herbicides at low dosages, but not single herbicides at higher dosages. Finally, considering that the transgenic enzymes HPPD and AAD12 confer resistance to more than one active ingredient, none of the companies included the full range of herbicides the crops are resistant to.

\section{Impact on food and feed risk assessment}

This chapter investigates the impact of different herbicide regimes on the risk assessment of food and feed products derived from HT GE plants. Since GMO and pesticide regulation are involved, both regulatory areas will be taken into account here.

\section{Pesticide risk assessment}

In general, it can be expected that HT GE crops and their harvested products, respectively, contain residues of the applied complementary herbicides. Which residues and degradation products are actually present depend on the plant species, the inserted genetic constructs as well as the herbicide regime. The latter comprises the kind of herbicide, the amount and frequency of application and the pre-harvest interval (PHI), which is the waiting time to harvest a crop after a pesticide application. It is noteworthy that a short PHI for glyphosate in some countries and some crop species is allowed for use as desiccant, which is especially relevant for cultivation of conventional crops.

Since HT GE crops and complementary herbicides form a technological package, specific agricultural practices can be applied. There are several issues that should be considered when assessing residues from complementary herbicides in GE crops, for example, specific patterns of application, exposure, occurrence of specific metabolites and emergence of combinatorial effects require special attention (see, for example, [11]).

It is obvious that, if agricultural practice raises the amounts that are sprayed, the amounts of residues in the harvest will increase as well [32]. Furthermore, crops with multiple herbicide resistance can be treated with herbicide combinations, and if so new residue patterns and new exposure patterns of the feed and food chain can be expected. Thus, for crops with multiple herbicide resistance, herbicide residues should be considered and assessed in combination before any authorisation for GE plants can be granted.

There are at least three relevant issues in the pesticide legislation (EU Regulation (EC) No 396/2005 and (EC) No 1107/2009): (i) the active ingredients and their metabolites have to be assessed to set maximum residue levels (MRL); (ii) the additives and synergists that are part of commercially produced herbicide formulations have to be taken into account insofar as these can leave residues in the harvest; (iii) the combinatorial effects should be taken into account if the crops are resistant to several active ingredients.

Each of these issues poses challenges for the food and feed safety of HT GE plants. Their risk assessment, performed according to the GMO regulation, is dependent on data from the pesticide risk assessment process to conclude on the overall safety of the final products. As yet there is no clear strategy for establishing the interface between pesticide and GMO regulation. However, this is necessary to systematically address the overlapping issues in the approval process. Under the current practice, these two areas of risk assessment are kept widely separated which causes well-documented major gaps in the overall safety assessment of these crops. We provide three examples.

\section{Missing data to set specific MRLs}

Even though active ingredients and their metabolites have to be assessed in accordance with Regulation (EC) No 396/2005 to set maximum residue levels (MRL), no such MRLs were set for isoxaflutole, because Bayer did not provide sufficient data [33]. This is worrying for the safety of sprayed soybeans because isoxaflutole is classified as a "suspected human carcinogen" by EFSA [33]. Further, metabolites of isoxaflutole were found in HT GE soybeans that had not previously been found in conventional soybeans because the plants cannot survive isoxaflutole. In regard to these metabolites, EFSA [33] stated that they were unable to evaluate risks to health from these new substances due to a lack of necessary data and therefore they could not set maximum limits for the amounts of these new residues in the harvest.

Also, there are knowledge gaps in the risk assessment of HT GE soybeans resistant to 2,4-D and glufosinate. When these crops are sprayed with 2,4-D, metabolites such as 2,4-dichlorophenol (2,4-DCP) can occur. These are regarded as more toxic than 2,4-D itself [34,35], but were not assessed by EFSA. In addition, glufosinate is 
classified in the EU as showing reproductive toxicity and is no longer approved for agricultural use in the EU [36].

\section{Missing data to assess additives and synergists in imports from third countries}

Commercial herbicide formulations applied onto plants in the EU are normally assessed in accordance with EU Regulation (EC) No 1107/2009. However, formulations sprayed in North and South America can escape this requirement (see below). This is relevant for the overall safety of products derived from HT plants, since there is a common understanding that commercially traded formulations of glyphosate, such as Roundup, can be more toxic than glyphosate itself [37-41].

The EU has already taken measures to remove problematic additives known as polyethoxylated tallow amine (POEA) from the market $[41,42]$. However, these additives can still be used in third countries for the cultivation of GE plants. It can be assumed from existing data that commercial mixtures used in fields in Argentina consist of about $50 \%$ glyphosate and about $15 \%$ additives known as POEA, which are much more toxic than glyphosate $[38,43]$.

The exact mixtures sprayed onto the plants are kept secret and treated as confidential business information. The EU Commission [44] has confirmed the respective gaps in risk assessment: "A significant amount of food and feed is imported into the EU from third countries. This includes food and feed produced from glyphosate-tolerant crops. Uses of glyphosate-based plant protection products in third countries are evaluated by the competent authorities in those countries against the locally prevailing regulatory framework, but not against the criteria of Regulation (EC) No 1107/2009 (...)." EFSA agrees that further investigations and data are needed [41, 45].

\section{No assessment of combinatorial effects}

Cumulative effects should be investigated if a plant contains or produces other compounds of potential toxicity. Regulation (EC) No 396/2005 on maximum residue levels of pesticides in food and feed of plant and animal origin also requests risk assessment of combinatorial effects. It is widely accepted that the combinatorial effects of herbicide residues can far exceed the toxicity of the single substances (see, for example, [46]). In addition, the EU Commission [47] confirmed that combinatorial effects should be investigated, while also indicating that adequate methods are not available: "It is true that the legislation requires cumulative and synergistic effects of pesticide residues to be considered in the MRL setting, but only when the methods will be available." This problem might only be solved in future: in 2019, EFSA published a new Guidance [48]; it compared the 'whole mixture approach' with a 'component-based approach' for the risk assessment of mixed toxicity that could also be applied in risk assessment of genetically engineered plants.

In conclusion, there is evidence of several gaps in the risk assessment of HT GE plants which can substantially reduce the reliability of food and feed risk assessment of products derived from these plants. The EFSA is the authority responsible for carrying out food and feed risk assessment in the EU; it appears to be aware of this problem. For example, in its assessment of residues from spraying various GM crops with glyphosate, EFSA [45] explicitly states that existing data are not sufficient to conclude on the health risks of consuming products derived from HT GE crops: "For genetically modified crops, data were sufficient to derive MRL for sweet corn (EPSPS modification) and cotton seed (EPSPS modification), noting that MRLs should be tentative pending on the submission of confirmatory methods for enforcement of AMPA and N-acetyl-glyphosate. For sugar beet roots, maize and soybeans (EPSPS modification), soybeans (GAT modification) and rapeseeds (GOX modification), the available data were insufficient to derive MRLs and risk assessment values." Similarly, already in 2015, EFSA pointed to insufficient data regarding additives such as POEA to assess food safety of HT GE crops [41]. However, so far, no regulatory conclusions or consequences have been drawn from these findings by the responsible risk managers, i.e. the EU Commission or the EU Member States.

\section{GMO risk assessment}

Crops and especially soybeans contain many biologically active substances, e.g. estrogens, allergens and anti-nutritional compounds, which may interact with trait-related characteristics and act as stressors $[49,50]$. Each of them can be characterised and quantified in isolation, but not all relevant substances of a given crop are known or taken into account when assessing food safety. Internationally agreed lists of nutritional compositional parameters to be analysed in soybean matrices for food or feed use only cover a limited number of the known biological substances: in the list suggested by the OECD [51], testing of the concentration of allergens is not required, pharmaceutically active ingredients, such as saponins, are not mentioned and not all known plant estrogens and known toxic substances are included.

Changes in plant composition cannot only be triggered by genetic interventions, but also by interactions with complementary herbicides. The latter is particularly relevant for soybeans: firstly, HT is the dominant transgenic trait in GE soybeans, and secondly, soybeans contain naturally high concentrations of phytoestrogens and allergens. The concentration of these substances can 
increase or decrease and may thereby impact the safety and nutritional composition of GE soybeans derived for food and feed. Table 5 gives an overview of publications reporting changes in the composition of glyphosateresistant GE soybeans and other parameters at different glyphosate dosages. It is evident that the respective changes can depend on the kind and concentration of the herbicide used. The applied dosages varied mostly in the range between approximately $1-3 \mathrm{~kg}$ (a.i.)/ha, only Correia [66] applying more than $6 \mathrm{~kg}$ (a.i.)/ha. The results show complex effects, both increasing and decreasing trends, evidencing both constitutional changes (e.g. content of protein, macro- and micronutrients, oil or sugar) and plant physiological and phenotypical changes (e.g. rate of photosynthesis, nitrogen fixation, plant biomass), depending on the applied doses of glyphosate. For example, Zobiole et al. [52] and also Bøhn et al. [53] found that glyphosate application can cause significant changes in soybean plant constituents. More specifically, Zobiole et al. [52] applied glyphosate at three different dosages (800 g, $1200 \mathrm{~g}$ and $2400 \mathrm{~g} / \mathrm{ha}$ ) which resulted in dose-correlated changes in plant compositions.

As recent research shows, there are previously undetected mechanisms which can cause compositional changes in glyphosate-resistant GE plants: Fang et al. [93] found that Arabidopsis engineered to be glyphosate resistant via an inserted mutated epsps gene exhibited a fecundity advantage in glyphosate-free environments. Apparently, the overproduced EPSPS protein interacted with plant metabolism. Since the plant hormone auxin plays a key role in growth, fecundity and adaptation to environmental stressors, the authors assumed that the overproduced EPSPS increased the auxin content. Consequently, the plant may produce more seeds and be more resistant to environmental stressors such as drought and heat. Also, the dosage and number of sprayings with the complementary herbicides could have an impact on these effects, since genome $x$ environment interactions often play an important role. Moreover, Fang et al. [93] observed that the effects were enhanced under stressful conditions.

Thus, if plants in field trials receive non-representative amounts of herbicides, this will not only impact the amount of herbicide residues, but could also conceal changes in plant composition and the interactions of biologically active compounds in a dose-response manner. Such changes can cause health risks, for instance by increasing the effects of allergens or phytoestrogens.

\section{Some further overlapping issues}

There are some further relevant issues in the risk assessments of HT GE plants and pesticides that require the establishment of a step-by-step interface process during the approval procedure [94]: for example, it should be taken into account that there may be specific interactions between residues of herbicides and plant constituents. This is particularly relevant for natural allergens and phytoestrogens in plants, since there are several indications that their risks to health can increase by interactions with compounds derived from glyphosate-based herbicides. Studies have shown that the endocrine system of young rats is disturbed when fed with soy milk in combination with glyphosate [95]. Several publications indicate that glyphosate formulations can act as so-called endocrine disruptors (see, for example, [96-102]). There may be synergistic or additive interactions of plant components in soybeans, such as isoflavones (see, for example, [103]), with residues from glyphosate formulations.

Furthermore, the potential impact of glyphosate residues on the intestinal microbiome needs to be considered. Some negative effects have already been shown for cattle [104], poultry [105] and rats [106]. As glyphosate has an antibiotic effect on certain widespread bacteria such as E. coli $[107,108]$, permanent exposure to glyphosate may also change the gut flora of humans. This issue is also relevant for sub-chronic low-dose exposure to 2,4-D [109]. Changes in the gut flora are suspected of being involved in many diseases (see, for example, [110, 111]). Adverse health effects via the microbiome might also be triggered by residues from spraying with the complementary herbicide (see also [112]). In general, antibiotic effects and other adverse impacts on the intestinal flora might occur from exposure to a diet containing HT plants, which is not assessed under the pesticide regulation.

Of significance, but not discussed here are the harmful health effects of glyphosate under occupational exposure (see, for example, $[16,113]$ ). In addition, it is noteworthy to remember that tank mixing herbicides with further adjuvants (most often surfactants) may have more severe or modified effects on non-target organisms than the herbicide formulations alone [114].

\section{Discussion}

To assess whether the expected agricultural practices under which GE plants are grown influence the studied end points, field trials with HT GE plants need to produce comparative data from plants treated, and not being treated, with the complementary herbicides under real agronomic conditions. As shown above, the application of herbicides will not only influence the presence, amount and composition of their residues, but can also impact gene expression, agronomic performance and plant composition. Since these issues are highly relevant for the assessment of health risks, it is important that the material chosen for testing the end 


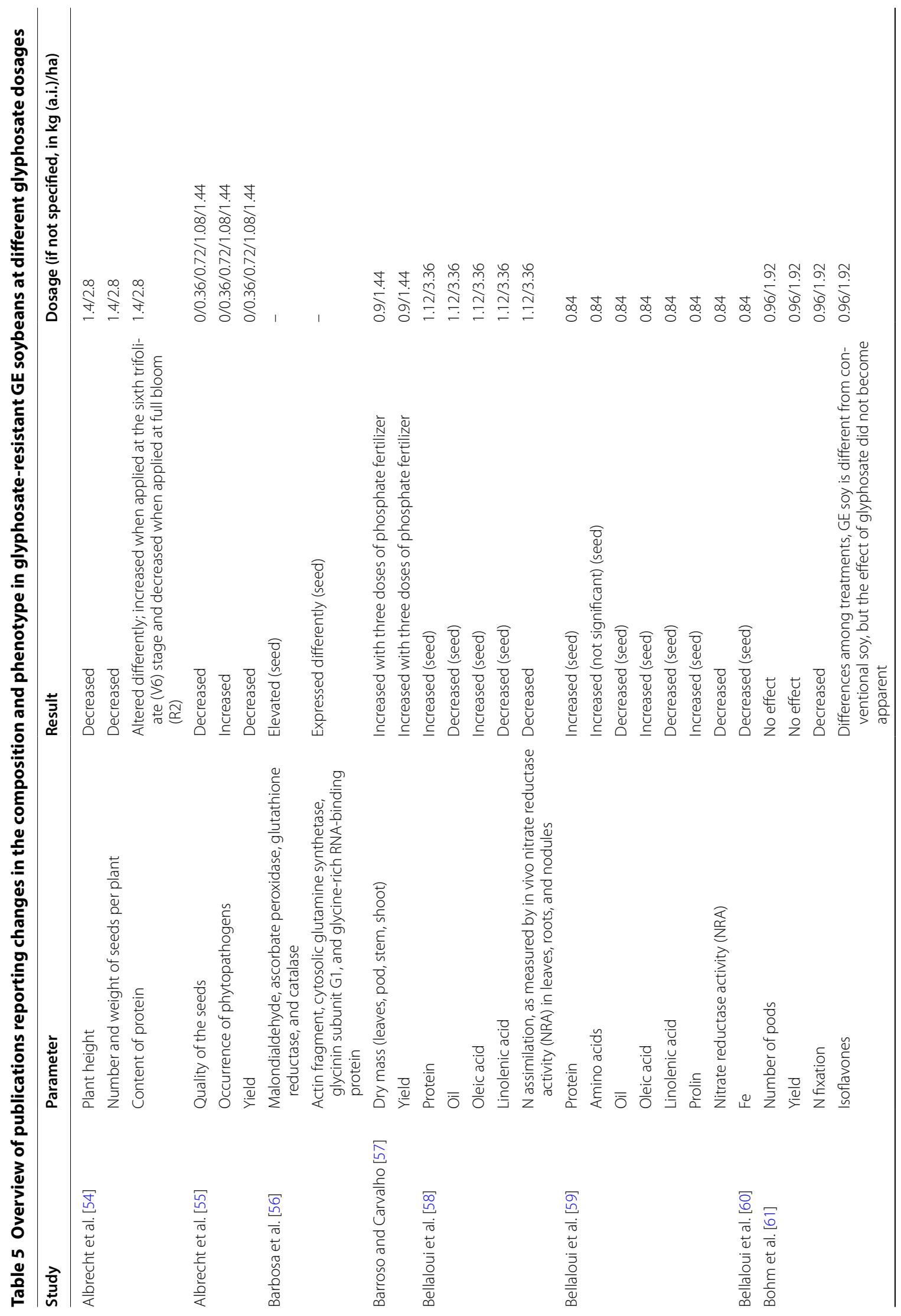




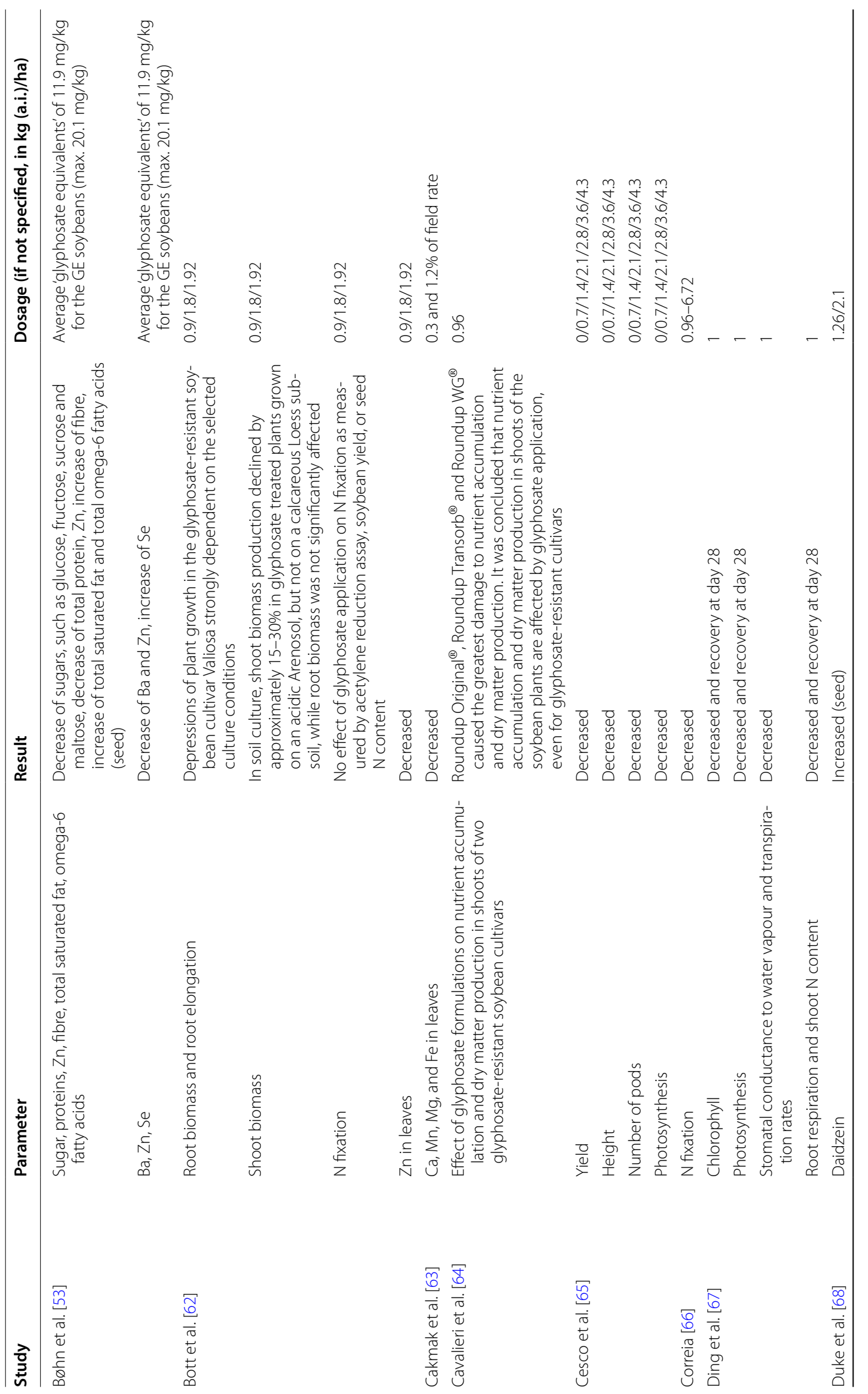




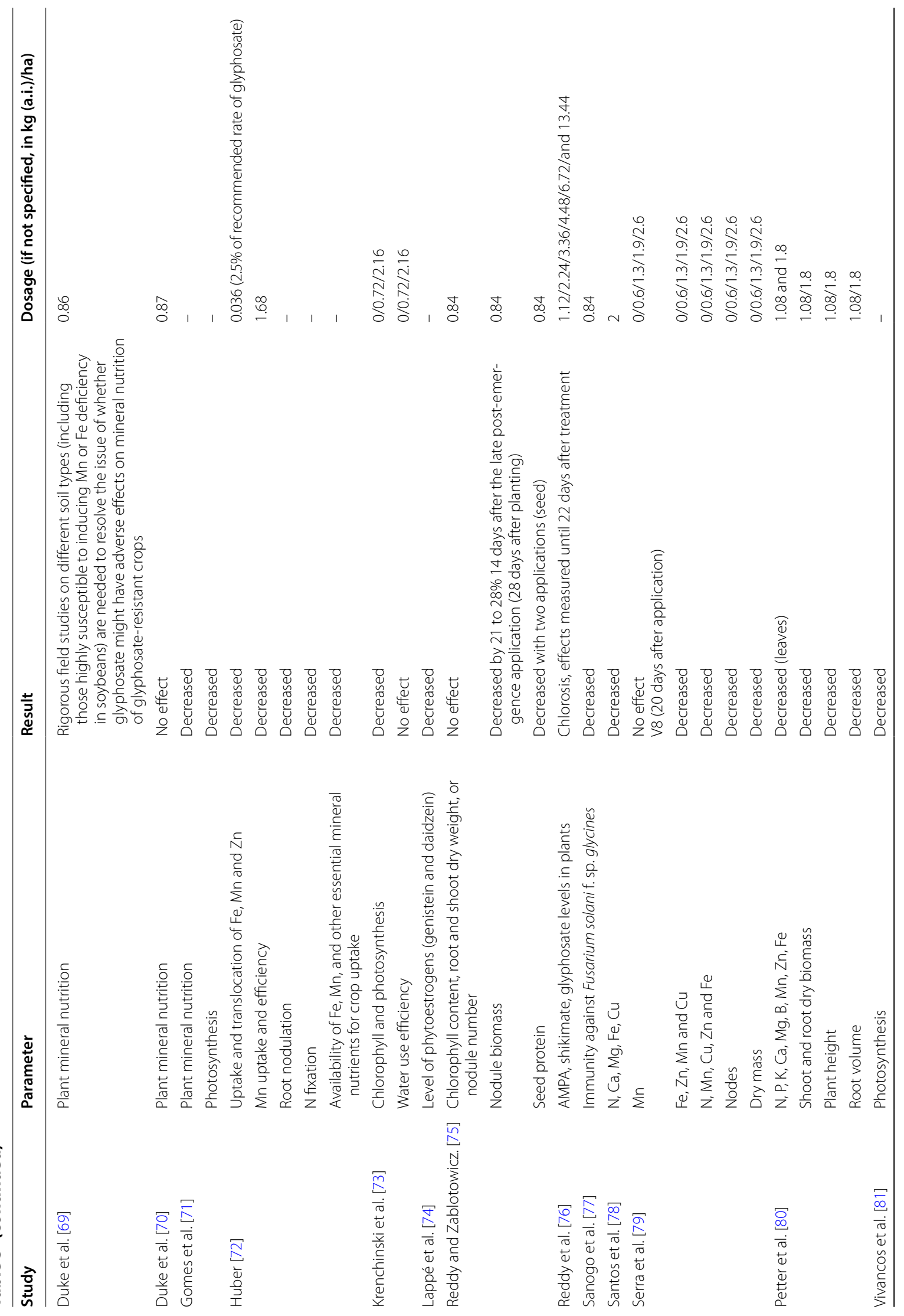




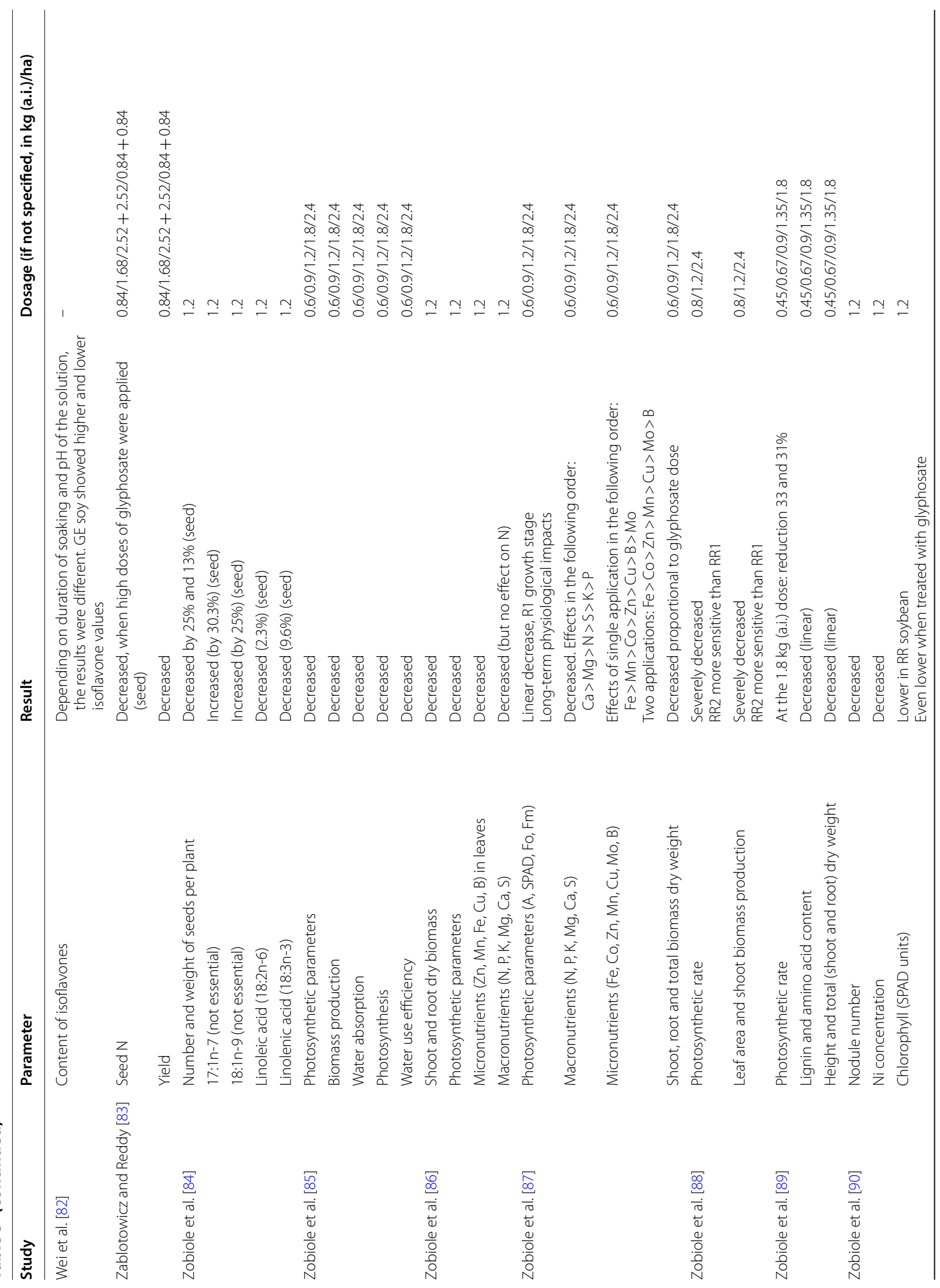




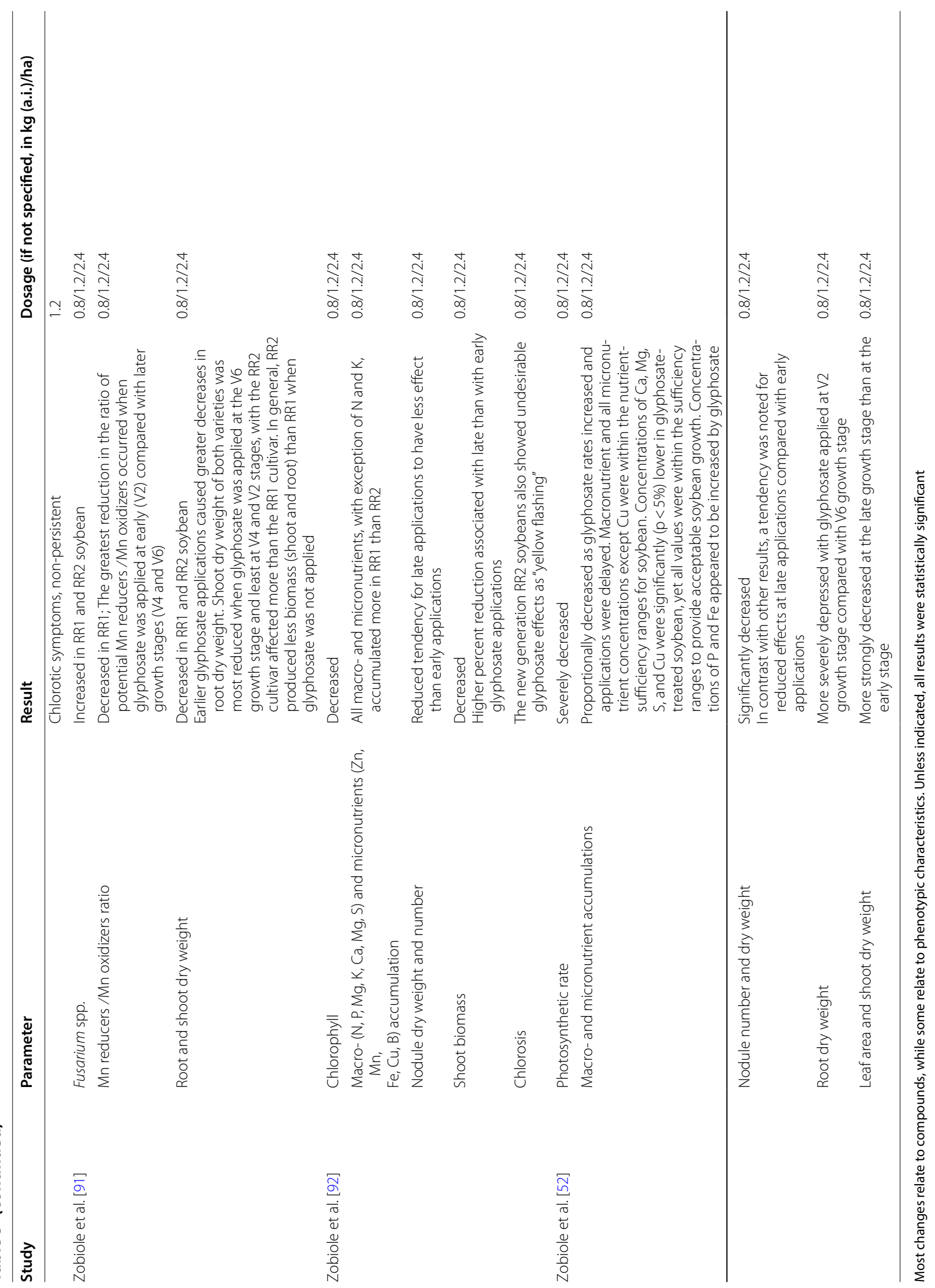


points and the applied herbicide regime are representative of the products that are actually imported into the EU.

Significant differences in plant composition can be expected even when conventionally bred varieties are compared to each other [115]. However, GE plants, especially those that produce additional EPSPS enzymes, can be expected to show differences which are caused by specific mechanisms (see, for example, [93]). Such specific molecular mechanisms can result in a plant composition that is changed in terms of quality and quantity. Field trials with the HT GE plants should be required to explore this issue ideally using the highest known dosage of the complementary herbicide applied by farmers or the highest dosage that can be tolerated by the plants. We emphasise that in most field trials, the dosage falls well below the maximum dosage recommended by the applicant (see sections "Current practice in the cultivation of HT GE soybeans in terms of use of complementary herbicides" and "Amount of glyphosate applied in field trials for EU approval process"). If information about real agronomic conditions is missing in the dossier requested for authorisation, this issue must be investigated and monitored. If the applied dosages in practice exceed the ones used in field trials, additional data has to be submitted to exclude unwanted changes in the GMO that may lead to adverse effects on human, animal and environmental health. Otherwise, the transgenic trait would not be described sufficiently and no conclusive risk assessment could be performed.

HT GE plants should also be tested under defined stress conditions (see for example [116]). This would allow defining the range of possible changes in the plant composition, agronomic performance, gene expression of introduced gene constructs and the level of residues (and metabolites) that can be expected. Such data would be useful to develop further hypotheses on the range of effects that should be considered as well as their potential impacts on health.

Clearly, the material used for comparative assessment must be produced under real agronomic practices, as requested under Regulation (EU) No 503/2013. Only then will the data from field trials be trustworthy and can represent the material entering the food and feed chain.

Based on our findings above, specific issues of major relevance for risk assessment of GE plants can be identified to improve the design of field trials and the assessment of the respective data:

(1) The herbicide dosage and the number of sprayings applied in the field trials: this aspect is highly relevant for the amount of residues found in harvested products, but also for the overall plant composition and combinatorial effects. Changes in agricultural practices need to be taken into account for new applications as well as for renewals.

(2) The specific herbicides used in field trials as single or combined applications: the known or otherwise expected agricultural practices for weed management during cultivation of GE with resistance to multiple active ingredients have to be taken into account. It is important to investigate whether the expected and approved varying practices for weed control influence plant composition and safety.

(3) The herbicide formulations used in the countries of cultivation: not only the active ingredients, but all relevant additives and synergists need to be taken into account in the overall risk assessment of the HT GE products for which authorisation for import is being sought.

(4) Toxicity of residues from spraying: GE plants should not be approved if the toxicity of the residues from the complementary herbicide is not fully determined.

(5) Potential combinatorial effects: the residues from the complementary herbicides and their mixed toxicity need also to be considered when assessing potential combinatorial effects and the overall safety of the relevant products; this includes also herbicide-plant (constituent) interactions.

(6) Direct and indirect effects in feeding studies: the immune system and the reproductive system should also be taken into account when testing the whole food and feed to assess possible health effects. Furthermore, indirect effects have to be considered that can be triggered via the intestinal microbiome as well as by cumulative or combinatorial effects caused, e.g. by specific dietary mixtures.

\section{Conclusion}

A large number of weeds (47 individual species globally [9]) have adapted to the massive use of glyphosate in agriculture and have become resistant. These HT weeds are an increasing problem in countries where HT GE crops are grown. Their widespread adoption has led to an accelerating amount of herbicides being used and has consequently led to an "arms race" in genetic engineering technology and usage of complementary herbicides. The increasing amount of herbicides sprayed onto these plants not only causes substantial problems in the environment [112, 117-123], but also creates new challenges for the risk assessment of health effects since products derived from these plants can introduce new herbicide residues into the food chain. 
The GMO and pesticide regulation provisions of the EU display a substantial overlap in terms of the requirements for the assessment of health risks: both regulatory areas require a high level of protection for health and the environment. Both request that the conditions of agricultural production are taken into account. Additionally, both request the evaluation of combinatorial effects. Finally, Implementing Regulation (EU) No 503/2013 explicitly combines the two areas of risk assessment by requesting field trials with and without the application of the complementary herbicide.

As shown, the dossiers currently submitted for market approval are seriously flawed: (i) herbicide applications in studies for risk assessment do not correspond with reallife farming practice; (ii) material prepared for feeding studies is different from the material entering the food chain; (iii) crucial data are missing for the safety testing of the residues from spraying and (iv) cumulative and combinatorial effects related to the application of the complementary herbicides as well as (v) herbicide-plant (constituent) interactions and long-term effects. Therefore, current dossiers cannot be considered to meet regulatory standards in the EU which require that safety for health and the environment is demonstrated.

Although our analyses focus on HT GE soybean, it can be anticipated that most of the outcomes also apply in principle to other HT GE crops, which are already or in the foreseeable future on the market, such as the MON 87429 corn which is resistant to four active ingredients [124].

We recommend the following requirements for the risk assessment of HT GE plants:

- All residues of active substances must be assessed, including taking various practical conditions into consideration (e.g. dosage and frequency of herbicide application, PHIs).

- All applied additives/adjuvants and their residues must be assessed.

- Combinatorial effects of the applied herbicides must be investigated, i.e. both herbicide-herbicide interactions, but also herbicide-plant (constituent) interactions.

- Potential changes in plant composition due to various herbicide applications must be investigated.

- Long-term effects of consumption of HT GE soybeans must be investigated, also including potential effects on the endocrine system, reproduction and the intestinal microbiome.

\section{Abbreviations}

EFSA: European Food Safety Authority; EPSPS: 5-enolpyruvylshikimate3-phosphate synthase; FAO/WHO: Food and Agriculture Organization of the United Nations/World Health Organization; GAT: glycine N-phenylacetyltransferase; GE: genetically engineered; GMO: genetically modified organism; GOX: glucose oxidase; HPPD: 4-hydroxyphenylpyruvate dioxygenase; HT: herbicide tolerant; MCPA: 2-methyl-4-chlorophenoxyacetic acid; MRLs: maximum residue levels; NRA: nitrate reductase activity; OECD: Organisation for Economic Co-operation and Development; PHI: pre-harvest interval; POEA: polyoxyethyleneamine; RR: Roundup Ready; USDA: United States Department of Agriculture.

\section{Acknowledgements}

The authors would especially like to thank the Mercator Foundation Switzerland and the Manfred-Hermsen-Stiftung.

\section{Authors' contributions}

$J M, A B P$ and $C T$ equally contributed to the report. TB and WR gave additional input and helped to finalise the publication. All authors read and approved the final manuscript.

\section{Funding}

The publication resulted from the RAGES project which is funded by the Mercator Foundation Switzerland. In addition, funding by Manfred-HermsenStiftung enabled targeted research of data in South America. Further funding came from Testbiotech.

\section{Availability of data and materials}

Not applicable.

\section{Competing interests}

The authors declare that they have no competing interests.

\section{Author details}

${ }^{1}$ Testbiotech e.V, Institute for Independent Impact Assessment of Biotechnology, Frohschammerstr. 14, 80807 Munich, Germany. ${ }^{2}$ Institute of Marine Research, PB 6404, N-9294 Tromsø, Norway. ${ }^{3}$ Federal Agency for Nature Conservation (BfN), Konstantinstrasse 110, 53179 Bonn, Germany.

Received: 27 June 2019 Accepted: 18 November 2019

Published online: 10 December 2019

References

1. EU Commission (2016) Genetically modified commodities in the EU, SWD (2016) 61 final, commission staff working document, Brussels. https://ec.europa.eu/transparency/regdoc/rep/10102/2016/EN/10102 -2016-61-EN-F1-1.PDF. Accessed 18 Sept 2019

2. EU Commission (2019) EU crops market observatory-oilseeds and protein crops. https://circabc.europa.eu/sd/a/4d9aeffa-bca9-49a3b3d3-28ca1a4e7520/oilseeds-monthly_trade-eurostat_en.xlsx. Accessed 18 Sept 2019

3. Testbiotech PlantGeneRisk - database on the authorisation of genetically engineered plants in the European Union. https://www.testbiotec h.org/database. Accessed 18 Sept 2019

4. Pengue WA (2005) Transgenic crops in Argentina: the ecological and social debt. Bull Sci Technol Soc 25(4):314-322. https://doi. org/10.1177/0270467605277290

5. Sankula S, Marmon G, Blumenthal E (2005) Biotechnology-derived crops planted in 2004: impacts on US agriculture. National Center for Food and Agricultural Policy, Washington, DC

6. Gianessi LP, Carpenter JE (2000) Agricultural biotechnology: benefits of transgenic soybeans, National Center for Food and Agricultural Policy(NCFAP), Washington DC. IATP. http://www.iatp.org/files/Agric ultural_Biotechnology_Benefits_of_Transge.pdf. Accessed 18 Sep 2019

7. Bradshaw LD, Padgette SR, Kimball SL, Wells BH (1997) Perspectives on glyphosate resistance. Weed Technol 11(1):189-198

8. Croon KA, Sidhu RS, Deatherage C (2000) Request for extension of determination of nonregulated additional regulated article: Roundup Ready corn line status to the NK603, study \# 99-884-U. APHIS, http:// 
www.aphis.usda.gov/brs/aphisdocs/00_01101p.pdf. Accessed 18 Sept 2019

9. Heap I (2019) The international survey of herbicide resistant weeds. http://www.weedscience.org/Summary/MOA.aspx?MOAID =12. Accessed 17 Sept 2019

10. Benbrook CM (2016) Trends in glyphosate herbicide use in the United States and globally. Environ Sci Eur 28:3. https://doi.org/10.1186/s1230 2-016-0070-0

11. Kleter GA, Unsworth JB, Harris CA (2011) The impact of altered herbicide residues in transgenic herbicide-resistant crops on standard setting for herbicide residues. Pest Manag Sci 67(10):1193-1210. https ://doi.org/10.1002/ps.2128

12. Bindraban PS, Franke AC, Ferraro DO, Ghersa CM, Lotz LAP, Nepomuceno A, Smulders MJM, Van de Wiel CCM (2009) GM-related sustainability: agro-ecological impacts, risk and opportunities of soy production in Argentina and Brazil. Plant Research International, Wageningen. WUR. https://wur.on.worldcat.org/oclc/401665298. Accessed 18 Sept 2019

13. Monsanto (2017) Roundup PowerMaxll product label. Greenbook. https ://assets.greenbook.net/16-50-19-15-03-2018-63045R2-9_PMAXII_Speci menLabel 2017.pdf. Accessed 18 Sept 2019

14. United States Department of Agriculture (USDA), National Agricultural Statistics Service (NASS) (20197) Agricultural chemical use program. http://www.nass.usda.gov/Surveys/Guide_to_NASS_Surveys/Chemi cal_Use/index Accessed 18 Sept 2019

15. Monsanto (2007) Cropping systems for managing weeds. Patent application WO2008051633, filed 06 Jun 2007

16. Avila-Vazquez M, Difilippo FS, Lean BM, Maturano E, Etchegoyen A (2018) Environmental exposure to glyphosate and reproductive health impacts in agricultural population of Argentina. J Environ Prot 9:241-253. https://doi.org/10.4236/jep.2018.93016

17. Primost JE, Marino DJG, Aparicio VC, Costa JL, Carriquiriborde P (2017) Glyphosate and AMPA, "pseudo-persistent" pollutants under real-world agricultural management practices in the Mesopotamic Pampas agroecosystem, Argentina. Environ Pollut 229:771-779. https://doi. org/10.1016/j.envpol.2017.06.006

18. Papa J, Tuesca D (2013) Los problemas actuales de malezase en la región sojera nucleo Argentina: Origen y alternativas de manejo. In: Rios A (ed) Viabilidad del glifosato en sistemas productivos sustentables. Unidad de Comunicación y Transferencia de Tecnología del INIA, Montevideo. AINFO, http://www.ainfo.inia.uy/digital/bitstream/ item/2551/1/18429080413103109.pdf\#page=67. Accessed 18 Sept 2019

19. Bombardi LM (2016) Pequeno ensaio cartográfico sobre o uso de agrotóxicos no Brasil. Laboratório de Geografia Agrária-USP, Blurb, São Paulo. OpenEdition. https://journals.openedition.org/confins/12594. Accessed 18 Sept 2019

20. Pignati W, Oliveira NP, da Silva AMC (2014) Vigilância aos agrotóxicos: quantificação do uso e previsão de impactos na saúde-trabalhoambiente para os municípios brasileiros. Ciência Saúde Coletiva 19(12):4669-4678. https://doi.org/10.1590/1413-812320141912.12762 014

21. Pignati WA, de Lima FA, de Lara SS, Correa MLM, Barbosa JR, da Leão LHC, Pignatti MG (2017) Distribuição espacial do uso de agrotóxicos no Brasil: uma ferramenta para a Vigilância em Saúde. Ciênc Saúde Coletiva 22(10):3281-3293. https://doi.org/10.1590/1413-812320172210.17742 017

22. Ontario Ministry of Agriculture, Food and Rural Affairs (OMAFRA) (2018) Publication 75A, Guide to weed control, field crops 2018. OMAFRA. http://www.omafra.gov.on.ca/english/crops/pub75/pub75A/pub75 A.pdf. Accessed 18 Sept 2019

23. Franceschell I (2015) Pobre Paracelso. In: Palau, M (ed) Con la soja al cuello: Informe sobre agronegocios en Paraguay 2013-2015. BASE Investigaciones Sociales, Asunción. BASEIS. http://www.baseis.org. py/wp-content/uploads/2015/12/2015Dic_ConLaSojaAlCuello.pdf. Accessed 18 Sept 2019

24. Perry ED, Ciliberto F, Hennessy DA, Moschini G (2016) Genetically engineered crops and pesticide use in U.S. maize and soybeans. Sci Adv 2(8):e1600850. https://doi.org/10.1126/sciadv.1600850

25. Testbiotech (2013) High levels of residues from spraying with glyphosate found in soybeans in Argentina. Testbiotech. https://www.testb iotech.org/node/926. Accessed 18 Sept 2019
26. de Almeida VES, Friedrich K, Tygel AF, Melgarejo L, Carneiro FF (2017) Use of genetically modified crops and pesticides in Brazil: growing hazards. Ciência Saúde Coletiva 22(10):3333-3339. https://doi. org/10.1590/1413-812320172210.17112017

27. European Food Safety Authority (EFSA) (2017) Scientific opinion on application EFSA-GMO-NL-2013-120 for authorisation of genetically modified soybean FG72 $\times$ A5547-127 for food and feed uses, import and processing submitted in accordance with Regulation (EC) No 1829/2003 by Bayer CropScience LP and M.S. Technologies LLC. EFSA J 15(4):e04744. https://doi.org/10.2903/j.efsa.2017.4744

28. European Food Safety Authority (EFSA) (2017) Scientific opinion on an application by Dow AgroSciences LLC (EFSA-GMO-NL-2012-106) for the placing on the market of genetically modified herbicide tolerant soybean DAS-44406-6 for food and feed uses, import and processing under Regulation (EC) No 1829/2003. EFSA J 15(3):e04738. https://doi. org/10.2903/j.efsa.2017.4738

29. Bayer CropScience AG (2011) New mutated hydroxyphenylpyruvate dioxygenase, DNA sequence and isolation of plants which are tolerant to HPPD inhibitor herbicides. WO2009144079 (A1), filed 10 Apr 2009

30. Schultz JL, Weber M, Allen J, Bradley KW (2015) Evaluation of weed management programs and response of FG72 soybean to HPPD-inhibiting herbicides. Weed Technol 29(4):653-664. https://doi.org/10.1614/ wt-d-14-00067.1

31. Dow AgroSciences (2006) Novel herbicide resistant genes. WIPO patent WO2007053482 filed 27 Oct 2006

32. Cuhra M (2015) Review of GMO safety assessment studies: glyphosate residues in Roundup Ready crops is an ignored issue. Environ Sci Eur 27:20. https://doi.org/10.1186/s12302-015-0052-7

33. European Food Safety Authority (EFSA) (2016) Peer review of the pesticide risk assessment of the active substance isoxaflutole. EFSA J 14(2):4416. https://doi.org/10.2903/j.efsa.2016.4416

34. Amer SM, Aly FAE (2001) Genotoxic effect of 2,4-dichlorophenoxy acetic acid and its metabolite 2,4-dichlorophenol in mouse. Mutat Res Toxicol Environ Mutagen 494:1-12. https://doi.org/10.1016/S1383 $-5718(01) 00146-2$

35. Lurquin PF (2016) Production of a toxic metabolite in 2,4-D-resistant GM crop plants. 3 Biotech 6:82. https://doi.org/10.1007/s13205-016-0387-9

36. European Commission (2019) Pesticides database (glufosinate). https ://ec.europa.eu/food/plant/pesticides/eu-pesticides-database/publi $c /$ ?event $=$ activesubstance.detail\&language $=E N \&$ selected $\mathrm{D}=1436$. Accessed 18 Sept 2019

37. Mesnage R, Defarge N, De Vendomois JS, Seralini G-E (2015) Potential toxic effects of glyphosate and its commercial formulations below regulatory limits. Food Chem Toxicol 84:133-153. https://doi.org/10.1016/j. fct.2015.08.012

38. Mesnage R, Benbrook C, Antoniou MN (2019) Insight into the confusion over surfactant co-formulants in glyphosate-based herbicides. Food Chem Toxicol 128:137-145. https://doi.org/10.1016/j.fct.2019.03.053

39. Richard S, Moslemi S, Sipahutar H, Benachour N, Seralini G-E (2005) Differential effects of glyphosate and Roundup on human placental cells and aromatase. Environ Health Perspect 113:716-720. https://doi. org/10.1289/ehp.7728

40. Benbrook CM (2019) How did the US EPA and IARC reach diametrically opposed conclusions on the genotoxicity of glyphosate-based herbicides? Environ Sci Eur 31(1):2. https://doi.org/10.1186/s1230 2-018-0184-7

41. European Food Safety Authority (EFSA) (2015) Request for the evaluation of the toxicological assessment of the co-formulant POE-tallowamine. EFSA J 13(11):4303. https://doi.org/10.2903/j.efsa.2015.4303

42. European Commission (2016) Commission implementing regulation (EU) 2016/1313 of 1 August 2016 amending Implementation Regulation (EU) No 540/2011 as regards the conditions of approval of the active substance glyphosate. https://eur-lex.europa.eu/eli/ reg_impl/2016/1313/oj. Accessed 18 Sept 2019

43. Pérez GL, Vera MS, Miranda L (2011) Effects of herbicide glyphosate and glyphosate-based formulations on aquatic ecosystems. In: Kortekamp A (ed) Herbicides and Environment. InTech, Rijeka. https://doi. org/10.5772/12877

44. European Commission (2016) Request to consider the impact of glyphosate residues in feed on animal health. Testbiotech. https:// www.testbiotech.org/content/eu-commission-request-consider-impac 
t-glyphosate-residues-feed-animal-health-february-2016. Accessed 18 Sept 2019

45. European Food Safety Authority (EFSA) (2018) Review of the existing maximum residue levels for glyphosate according to Article 12 of Regulation (EC) No 396/2005. EFSA J 16(5):e05263. https://doi.org/10.2903/j. efsa.2018.5263

46. Reuter W (2015) Toxicology of glyphosate, isoxaflutole, dicamba and possible combination effects. Testbiotech. www.testbiotech.org/sites /default/files/Tox_Evaluation_Glyphosate_Dicamba_Isoxaflutole.pdf. Accessed 18 Sept 2019

47. European Commission (2016) Letter from the EU Commission sent with the decision to authorise FG 72, MON $88708 \times$ MON89788 and MON 87705 x MON 89788 soybeans. Testbiotech. https://www.testbiotec h.org/content/letter-eu-commission-sent-decision-authorise-toxic -soybeans-august-2016. Accessed 18 Sept 2019

48. European Food Safety Authority (EFSA) (2019) Guidance on harmonised methodologies for human health, animal health and ecological risk assessment of combined exposure to multiple chemicals. EFSA J 17(3):e05634. https://doi.org/10.2903/j.efsa.2019.5634

49. Kurosu M (2011) Biologically active molecules from soybeans. In: El-Shemy H (ed) Soybean and Health. InTech, Rijeka. http://www.intec hopen.com/books/soybean-and-health/biologically-active-moleculesfrom-soybeans

50. Cabrera-Orozco A, Jiménez-Martínez C, Dávila-Ortiz G (2013) Soybean: non-nutritional factors and their biological functionality. In: El-Shemy HA (ed) Soybean-bio-active compounds. InTech, Rijeka. https://pdfs. semanticscholar.org/9de4/fb850649f3b7f2026be5bb967f532f84d41 6.pdf

51. Organisation for Economic Co-operation and Development (OECD) (2012) Revised consensus document on compositional considerations for new varieties of soybean [Glycine max (L.) Merr.]: key food and feed nutrients, antinutrients, toxicants and allergens. Series on the Safety of Novel Foods and Feeds No. 25 ENV/JM/MONO, 24. http://www.oecd. org/officialdocuments/publicdisplaydocumentpdf/?cote=env/jm/ mono(2012)24\&doclanguage=en. Accessed 18 Sept 2019

52. Zobiole LHS, Kremer RJ, de Oliveira Jr RS, Constantin J (2012) Glyphosate effects on photosynthesis, nutrient accumulation, and nodulation in glyphosate resistant soybean. J Plant Nutr Soil Sci 175(2):319-330. https://doi.org/10.1002/jpln.201000434

53. Bøhn T, Cuhra M, Traavik T, Sanden M, Fagan J, Primicerio R (2014) Compositional differences in soybeans on the market: glyphosate accumulates in Roundup Ready GM soybeans. Food Chem 153:207-215. https://doi.org/10.1016/j.foodchem.2013.12.054

54. Albrecht L, Barbosa A, Silva AF, Mendes M, Maraschi-Silva L, Albrecht AJ (2011) Desempenho da soja roundup ready sob aplicação de glyphosate em diferentes estádios. Planta Daninha 29:585-590. https://doi. org/10.1590/s0100-83582011000300012

55. Albrecht LP, Albrecht AJP, Braccini AL, Oliveira RS Jr, Zobiole LHS, Ávila MR (2014) The role of glyphosate in RR soybean production and seed quality. Planta Daninha 32:401-407. https://doi.org/10.1590/s0100 $-83582014000200018$

56. Barbosa HS, Arruda SCC, Azevedo RA, Arruda MAZ (2012) New insights on proteomics of transgenic soybean seeds: evaluation of differential expressions of enzymes and proteins. Anal Bioanal Chem 402:299-314. https://doi.org/10.1007/s00216-011-5409-1

57. Barroso AAM, de Carvalho LB (2018) Glyphosate resistant soybean growth and yield affected by glyphosate and phosphate fertilization. Aust J Crop Sci 12:1718-1724. https://search.informit.com.au/docum entSummary; $\mathrm{dn}=096729458617903$;res=IELHSS

58. Bellaloui N, Zablotowicz RM, Reddy KN, Abel CA (2008) Nitrogen metabolism and seed composition as influenced by glyphosate application in glyphosate-resistant soybean. J Agric Food Chem 56:2765-2772. https ://doi.org/10.1021/jf703615m

59. Bellaloui N, Abbas HK, Gillen AM, Abel CA (2009) Effect of glyphosateboron application on seed composition and nitrogen metabolism in glyphosate-resistant soybean. J Agric Food Chem 57:9050-9056. https ://doi.org/10.1021/jf901801z

60. Bellaloui N, Reddy KN, Zablotowicz RM, Abbas HK, Abel CA (2009) Effects of glyphosate application on seed iron and root ferric (III) reductase in soybean cultivars. J Agric Food Chem 57:9569-9574. https://doi. org/10.1021/jf902175y
61. Bärwald Bohm GM, Rombaldi CV, Genovese MI, Castilhos D, Rodrigues Alves BJ, Rumjanek NG (2014) Glyphosate effects on yield, nitrogen fixation, and seed quality in glyphosate-resistant soybean. Crop Sci 54:1737. https://doi.org/10.2135/cropsci2013.07.0470

62. Bott S, Tesfamariam T, Candan H, Cakmak I, Römheld V, Neumann G (2008) Glyphosate-induced impairment of plant growth and micronutrient status in glyphosate-resistant soybean (Glycine max L.). Plant Soil 312:185-194. https://doi.org/10.1007/s11104-008-9760-8

63. Cakmak I, Yazici A, Tutus Y, Ozturk L (2009) Glyphosate reduced seed and leaf concentrations of calcium, manganese, magnesium, and iron in non-glyphosate resistant soybean. Eur J Agron 31:114-119. https:// doi.org/10.1016/j.eja.2009.07.001

64. Cavalieri SD, Velini ED, Silva FML, São José AR, Andrade GJ (2012) Acúmulo de nutrientes e matéria seca na parte aérea de dois cultivares de soja RR sob efeito de formulações de glyphosate. Planta Daninha 30:349-358. https://doi.org/10.1590/s0100-83582012000200014

65. Cesco VJS, Krenchinski FH, Rodrigues DM, Nardi R, Albrecht AJP, Albrecht LP (2018) Agronomic performance of intacta RR2 soybean submitted to doses of glyphosate. Planta Daninha 36:e018168727. https://doi. org/10.1590/s0100-83582018360100109

66. Correia AMP (2013) Desempenho de soja transgênica ao glifosato e seu efeito na nodulação e produtividade da cultura, Dissertação (Mestrado em Produção Vegetal). Universidade Federal da Grande Dourados, Dourados MatoGrosso do Sul. Docplayer. https://docplayer.com. br/5844277-Universidade-federal-da-grande-dourados-desempenho -de-soja-transgenica-ao-glifosato-e-seu-efeito-na-nodulacao-e-produ tividade-da-cultura.html. Accessed 18 Sept 2019

67. Ding W, Reddy KN, Zablotowicz RM, Bellaloui N, Arnold Bruns H (2011) Physiological responses of glyphosate-resistant and glyphosatesensitive soybean to aminomethylphosphonic acid, a metabolite of glyphosate. Chemosphere 83:593-598. https://doi.org/10.1016/j.chemo sphere.2010.12.008

68. Duke SO, Rimando AM, Pace PF, Reddy KN, Smeda RJ (2003) Isoflavone, glyphosate, and aminomethylphosphonic acid levels in seeds of glyphosate-treated, glyphosate-resistant soybean. J Agric Food Chem 51:340-344. https://doi.org/10.1021/jf025908i

69. Duke SO, Lydon J, Koskinen WC, Moorman TB, Chaney RL, Hammerschmidt R (2012) Glyphosate effects on plant mineral nutrition, crop rhizosphere microbiota, and plant disease in glyphosate-resistant crops. J Agric Food Chem 60:10375-10397. https://doi.org/10.1021/jf302436u

70. Duke SO, Rimando AM, Reddy KN, Cizdziel JV, Bellaloui N, Shaw DR, Williams MM, Maul JE (2017) Lack of transgene and glyphosate effects on yield, and mineral and amino acid content of glyphosate-resistant soybean. Pest Manag Sci 74:1166-1173. https://doi.org/10.1002/ps.4625

71. Gomes MP, Smedbol E, Chalifour A, Hénault-Ethier L, Labrecque M, Lepage L, Lucotte M, Juneau P (2014) Alteration of plant physiology by glyphosate and its by-product aminomethylphosphonic acid: an overview. J Exp Bot 65:4691-4703. https://doi.org/10.1093/jxb/eru269

72. Huber DM (2007) What about glyphosate-induced manganese deficiency. Fluid J 15:20-22. Grazing Bestprac. http://www.grazingbestprac .com.au/research/chemicals/Huber\%20Glyphosate\%2058P20-22.pdf. Accessed 18 Sept 2019

73. Krenchinski FH, Albrecht LP, Albrecht AJP, Cesco VJS, Rodrigues DM, Portz RL, Zobiole LHS (2017) Glyphosate affects chlorophyll, photosynthesis and water use of four Intacta RR2 soybean cultivars. Acta Physiol Plant 39:63. https://doi.org/10.1007/s11738-017-2358-0

74. Lappé MA, Bailey EB, Childress C, Setchell KD (1998) Alterations in clinically important phytoestrogens in genetically modified, herbicidetolerant soybeans. J Med Food 1:241-245. https://doi.org/10.1089/ jmf.1998.1.241

75. Reddy KN, Zablotowicz RM (2003) Glyphosate-resistant soybean response to various salts of glyphosate and glyphosate accumulation in soybean nodules. Weed Sci 51:496-502. https://doi.org/10.1614/00431745(2003)051\%5B0496:GSRTVS\%5D2.0.CO;2

76. Reddy KN, Rimando AM, Duke SO (2004) Aminomethylphosphonic acid, a metabolite of glyphosate, causes injury in glyphosate-treated, glyphosate-resistant soybean. J Agric Food Chem 52:5139-5143. https ://doi.org/10.1021/jf049605v

77. Sanogo S, Yang XB, Scherm H (2000) Effects of herbicides on Fusarium solani f. sp. glycines and development of sudden death syndrome in 
glyphosate-tolerant soybean. Phytopathology 90:57-66. https://doi. org/10.1094/PHYTO.2000.90.1.57

78. Santos JB, Ferreira EA, Reis MR, Silva AA, Fialho CMT, Freita MAM (2007) Avaliação de formulações de glyphosate sobre soja Roundup Ready. Planta Daninha 25:165-171. https://doi.org/10.1590/s0100-8358200700 0100018

79. Serra AP, Marchetti ME, da Candido SAC, Dias ACR, Christoffoleti PJ (2011) Glyphosate influence on nitrogen, manganese, iron, copper and zinc nutritional efficiency in glyphosate resistant soybean. Ciência Rural 41:77-84. https://doi.org/10.1590/50103-84782011000100013

80. Petter FA, Zuffo AM, de Alcântara Neto F, Pacheco LP, de Almeida FA, Andrade FR, Júnior JMZ (2016) Effect of glyphosate and water stress on plant morphology and nutrient accumulation in soybean. Aust J Crop Sci 10:251. https://search.informit.com.au/documentSu mmary; $d n=031115506226791$; res=IELHSS

81. Vivancos PD, Driscoll SP, Bulman CA, Ying L, Emami K, Treumann A, Mauve C, Noctor G, Foyer CH (2011) Perturbations of amino acid metabolism associated with glyphosate-dependent inhibition of shikimic acid metabolism affect cellular redox homeostasis and alter the abundance of proteins involved in photosynthesis and photorespiration. Plant Physiol 157(1):256-268. https://doi.org/10.1104/ pp.111.181024

82. Wei Q-K, Jone WW, Fang TJ (2004) Study on isoflavones isomers contents in Taiwan's soybean and GM soybean. J Food Drug Anal 12:324-331. https://www.researchgate.net/publication/27990 1447_Study_on_isoflavones_isomers_contents_in_Taiwan's_soybe an_and_GM_soybean

83. Zablotowicz RM, Reddy KN (2007) Nitrogenase activity, nitrogen content, and yield responses to glyphosate in glyphosate-resistant soybean. Crop Prot 26:370-376. https://doi.org/10.1016/j.cropr 0.2005 .05 .013

84. Zobiole LH, Oliveira RS Jr, Visentainer JV, Kremer RJ, Bellaloui N, Yamada $T$ (2010) Glyphosate affects seed composition in glyphosate-resistant soybean. J Agric Food Chem 58(7):4517-4522. https://doi.org/10.1021/ jf904342t

85. Zobiole LHS, de Oliveira Jr RS, Kremer RJ, Constantin J, Bonato CM, Muniz AS (2010) Water use efficiency and photosynthesis of glyphosate-resistant soybean as affected by glyphosate. Pestic Biochem Physiol 97(3):182-193. https://doi.org/10.1016/j.pestbp.2010.01.004

86. Zobiole LHS, de Oliveira RS, Huber DM, Constantin J, de Castro C, de Oliveira FA, de Oliveira A (2010) Glyphosate reduces shoot concentrations of mineral nutrients in glyphosate-resistant soybeans. Plant Soil 328(1-2):57-69. https://doi.org/10.1007/s11104-009-0081-3

87. Zobiole LHS, de Junior RS, Kremer RJ, Muniz AS, de Junior A (2010) Nutrient accumulation and photosynthesis in glyphosate-resistant soybeans is reduced under glyphosate use. J Plant Nutr 33(12):1860-1873. https://doi.org/10.1080/01904167.2010.491890

88. Zobiole LHS, Kremer RJ, de Oliveira RS, Constantin J (2010) Glyphosate affects photosynthesis in first and second generation of glyphosate-resistant soybeans. Plant Soil 336(1-2):251-265. https://doi. org/10.1007/s11104-010-0474-3

89. Zobiole LHS, Bonini EA, de Oliveira RS, Kremer RJ, Ferrarese-Filho $O$ (2010) Glyphosate affects lignin content and amino acid production in glyphosate-resistant soybean. Acta Physiol Plant 32(5):831-837. https:// doi.org/10.1007/s11738-010-0467-0

90. Zobiole LHS, Oliveira RS Jr, Kremer RJ, Constantin J, Yamada T, Castro C, Oliveira FA, Oliveira A Jr (2010) Effect of glyphosate on symbiotic $\mathrm{N}_{2}$ fixation and nickel concentration in glyphosate-resistant soybeans. Appl Soil Ecol 44(2):176-180. https://doi.org/10.1016/j.apsoil.2009.12.003

91. Zobiole LHS, Kremer RJ, Oliveira RS, Constantin J (2010) Glyphosate affects micro-organisms in rhizospheres of glyphosate-resistant soybeans. J Appl Microbiol 110(1):118-127. https://doi.org/10.111 $1 / j .1365-2672.2010 .04864 . x$

92. Zobiole LH, Kremer RJ, Oliveira RS Jr, Constantin J (2011) Glyphosate affects chlorophyll, nodulation and nutrient accumulation of "second generation" glyphosate-resistant soybean (Glycine max L.). Pestic Biochem Physiol 99(1):53-60. https://doi.org/10.1016/j.pestbp.2010.10.005

93. Fang J, Nan P, Gu Z, Ge X, Feng Y-Q, Lu B-R (2018) Overexpressing exogenous 5-enolpyruvylshikimate-3-phosphate synthase (EPSPS) genes increases fecundity and auxin content of transgenic Arabidopsis plants. Front Plant Sci 9:233. https://doi.org/10.3389/fpls.2018.00233
94. Then C, Bauer-Panskus A (2017) Possible health impacts of Bt toxins and residues from spraying with complementary herbicides in genetically engineered soybeans and risk assessment as performed by the European Food Safety Authority EFSA. Environ Sci Eur 29:1. https://doi. org/10.1186/s12302-016-0099-0

95. Nardi J, Moras PB, Koeppe C, Dallegrave E, Leal MB, Rossato-Grando LG (2017) Prepubertal subchronic exposure to soy milk and glyphosate leads to endocrine disruption. Food Chem Toxicol 100:247-252. https:// doi.org/10.1016/j.fct.2016.12.030

96. Thongprakaisang S, Thiantanawat A, Rangkadilok N, Suriyo T, Satayavivad J (2013) Glyphosate induces human breast cancer cells growth via estrogen receptors. Food Chem Toxicol 59:129-136. https://doi. org/10.1016/j.fct.2013.05.057

97. Çağlar S, Kolankaya D (2008) The effect of sub-acute and sub-chronic exposure of rats to the glyphosate-based herbicide Roundup. Environ Toxicol Pharmacol 25(1):57-62. https://doi.org/10.1016/j. etap.2007.08.011

98. Cavalli VLDLO, Cattani D, Heinz Rieg CE, Pierozan P, Zanatta L, Benedetti Parisotto E, Wilhelm Filho D, Mena Barreto Silva FR, Pessoa-Pureur R, Zamoner A (2013) Roundup disrupts male reproductive functions by triggering calcium-mediated cell death in rat testis and Sertoli cells. Free Radic Biol Med 65:335-346. https://doi.org/10.1016/j.freeradbio med.2013.06.043

99. Omran NE, Salama WM (2016) The endocrine disruptor effect of the herbicides atrazine and glyphosate on Biomphalaria alexandrina snails. Toxicol Ind Health 32(4):656-665. https://doi.org/10.1177/0748233713 506959

100. Manservisi F, Lesseur C, Panzacchi S, Mandrioli D, Falcioni L, Bua L, Manservigi M, Spinaci M, Galeati G, Mantovani A, Lorenzetti S, Miglio R, Andrade AM, Kristensen DM, Perry MJ, Swan SH, Chen J, Belpoggi F (2019) The Ramazzini Institute 13-week pilot study glyphosate-based herbicides administered at human-equivalent dose to Sprague Dawley rats: effects on development and endocrine system. Environ Health 18:15. https://doi.org/10.1186/s12940-019-0453-y

101. Pham TH, Derian L, Kervarrec C, Kernanec P-Y, Jégou B, Smagulova F, Gely-Pernot A (2019) Perinatal exposure to glyphosate and a glyphosate-based herbicide affect spermatogenesis in mice. Toxicol Sci 169:260-271. https://doi.org/10.1093/toxsci/kfz039

102. Gomez AL, Altamirano GA, Leturia J, Bosquiazzo VL, Muñoz-de-Toro M, Kass L (2019) Male mammary gland development and methylation status of estrogen receptor alpha in Wistar rats are modified by the developmental exposure to a glyphosate-based herbicide. Mol Cell Endocrinol 481:14-25. https://doi.org/10.1016/j.mce.2018.11.005

103. de Lemos ML (2001) Effects of soy phytoestrogens genistein and daidzein on breast cancer growth. Ann Pharmacother 35(9):1118-1121. https://doi.org/10.1345/aph.10257

104. Reuter T, Alexander TW, Martínez TF, McAllister TA (2007) The effect of glyphosate on digestion and horizontal gene transfer during in vitro ruminal fermentation of genetically modified canola. J Sci Food Agric 87(15):2837-2843.https://doi.org/10.1002/jsfa.3038

105. Shehata AA, Schrödl W, Aldin AA, Hafez HM, Krüger M (2012) The effect of glyphosate on potential pathogens and beneficial members of poultry microbiota in vitro. Curr Microbiol 66(4):350-358. https://doi. org/10.1007/s00284-012-0277-2

106. Mao Q, Manservisi F, Panzacchi S, Mandrioli D, Menghetti I, Vornoli A, Bua L, Falcioni L, Lesseur C, Chen J, Belpoggi F, Hu J (2018) The Ramazzini Institute 13-week pilot study on glyphosate and Roundup administered at human-equivalent dose to Sprague Dawley rats: effects on the microbiome. Environ Health 17:50. https://doi.org/10.1186/ s12940-018-0394-x

107. Forlani G, Kafarski P, Lejczak B, Wieczorek P (1997) Mode of action of herbicidal derivatives of aminomethylenebisphosphonic acid. Part II. Reversal of herbicidal action by aromatic amino acids. J Plant Growth Regul 16(3):147-152. https://doi.org/10.1007/pl00006989

108. Carlisle SM, Trevors JT (1988) Glyphosate in the environment. Water Air Soil Pollut 39(3-4):409-420. https://doi.org/10.1007/BF00279485

109. Tu P, Gao B, Chi L, Lai Y, Bian X, Ru H, Lu K (2019) Subchronic low-dose 2,4-D exposure changed plasma acylcarnitine levels and induced gut microbiome perturbations in mice. Sci Rep 9:4363. https://doi. org/10.1038/s41598-019-40776-3 
110. Williams MR, Stedtfeld RD, Tiedje JM, Hashsham SA (2017) MicroRNAsbased inter-domain communication between the host and members of the gut microbiome. Front Microbiol 8:1896. https://doi.org/10.3389/ fmicb.2017.01896

111. Tremaroli V, Bäckhed F (2012) Functional interactions between the gut microbiota and host metabolism. Nature 489:242-249. https://doi. org/10.1038/nature11552

112. Van Bruggen AHC, He MM, Shin K, Mai V, Jeong KC, Finckh MR, Morris JG (2018) Environmental and health effects of the herbicide glyphosate. Sci Total Environ 616-617:255-268. https://doi.org/10.1016/j.scito tenv.2017.10.309

113. Bernieri T, Rodrigues D, Barbosa IR, Ardenghi PG, Basso da Silva L (2019) Occupational exposure to pesticides and thyroid function in Brazilian soybean farmers. Chemosphere 218:425-429. https://doi.org/10.1016/j. chemosphere.2018.11.124

114. Niedobová J, Skalský M, Ouředníčková J, Michalko R, Bartošková A (2019) Synergistic effects of glyphosate formulation herbicide and tankmixing adjuvants on Pardosa spiders. Environ Pollut 249:338-344. https ://doi.org/10.1016/j.envpol.2019.03.031

115. McClain S, Stevenson SE, Brownie C, Herouet-Guicheney C, Herman RA, Ladics GS, Privalle L, Ward JM, Doerrer N, Thelen JJ (2018) Variation in seed allergen content from three varieties of soybean cultivated in nine different locations in lowa, Illinois, and Indiana. Front Plant Sci 9:1025. https://doi.org/10.3389/fpls.2018.01025

116. Trtikova M, Wikmark OG, Zemp N, Widmer A, Hilbeck A (2015) Transgene expression and Bt protein content in transgenic Bt maize (MON810) under optimal and stressful environmental conditions. PLoS ONE 10(4):e0123011. https://doi.org/10.1371/journal.pone.0123011

117. Schütte $G$, Eckerstorfer M, Rastelli V, Reichenbecher W, Restrepo-Vassalli S, Ruohonen-Lehto M, Wust Saucy A-G, Mertens M (2017) Herbicide resistance and biodiversity: agronomic and environmental aspects of genetically modified herbicide-resistant plants. Environ Sci Eur 29:5. https://doi.org/10.1186/s12302-016-0100-y

118. Bai SH, Ogbourne SM (2016) Glyphosate: environmental contamination, toxicity and potential risks to human health via food contamination.
Environ Sci Pollut Res 23(19):18988-19001. https://doi.org/10.1007/ s11356-016-7425-3

119. Tsatsakis AM, Nawaz MA, Kouretas D, Balias G, Savolainen K, Tutelyan VA, Golokhvast KS, Lee JD, Yang SH, Chung G (2017) Environmental impacts of genetically modified plants: a review. Environ Res 156:818-833. https ://doi.org/10.1016/j.envres.2017.03.011

120. Richmond ME (2018) Glyphosate: a review of its global use, environmental impact, and potential health effects on humans and other species. J Environ Stud Sci 8(4):416-434. https://doi.org/10.1007/s1341 2-018-0517-2

121. Aparicio VC, De Gerónimo E, Marino D, Primost J, Carriquiriborde P, Costa JL (2013) Environmental fate of glyphosate and aminomethylphosphonic acid in surface waters and soil of agricultural basins. Chemosphere 93(9):1866-1873. https://doi.org/10.1016/j.chemospher e.2013.06.041

122. Annett R, Habibi HR, Hontela A (2014) Impact of glyphosate and glyphosate-based herbicides on the freshwater environment. J Appl Toxicol 34(5):458-479. https://doi.org/10.1002/jat.2997

123. Herrera LP, Panigatti JL, Barral MP, Blanco DE (2013) Biofuels in Argentina impacts of soybean production on wetlands and water. B Aires Wetl Int. https://www.researchgate.net/publication/289249051

124. Government of Canada CFIA (2019) Notice of submission from Monsanto Canada ULC for novel food, livestock feed and environmental safety approval for commercial planting purposes of a plant genetically modified for herbicide tolerance. https://www.inspection.gc.ca/plants/ plants-with-novel-traits/notices-of-submission/mon-87429/eng/15605 17631374/1560517631624. Accessed 19 Sept 2019

\section{Publisher's Note}

Springer Nature remains neutral with regard to jurisdictional claims in published maps and institutional affiliations.

\section{Submit your manuscript to a SpringerOpen ${ }^{\circ}$ journal and benefit from:}

- Convenient online submission

- Rigorous peer review

- Open access: articles freely available online

- High visibility within the field

- Retaining the copyright to your article

Submit your next manuscript at $\boldsymbol{\nabla}$ springeropen.com 